\title{
El profesional de la información (EPI): Bibliometric and thematic analysis (2006-2017)
}

\author{
José-Ricardo López-Robles; Javier Guallar; José-Ramón Otegi-Olaso; Nadia-Karina \\ Gamboa-Rosales
}

Nota: Este artículo se puede leer en español en:

http://www.elprofesionaldelainformacion.com/contenidos/2019/jul/lopez-guallar-otegi-gamboa_es.pdf

How to cite this article:

López-Robles, José-Ricardo; Guallar, Javier; Otegi-Olaso, José-Ramón; Gamboa-Rosales, Nadia-Karina (2019).

"El profesional de la información (EPI): bibliometric and thematic analysis (2006-2017)". El profesional de la información, v. 28, n. 4, e280417.

https://doi.org/10.3145/epi.2019.jul.17

Manuscript received on $24^{\text {th }}$ February 2019 Accepted on $03^{\text {th }}$ July 2019

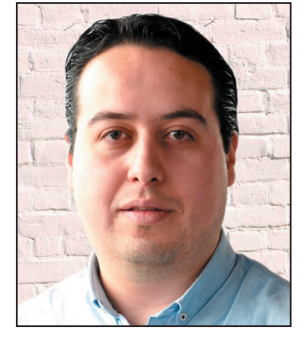

José-Ricardo López-Robles $\bowtie$ http://orcid.org/0000-0003-3780-1955

Universidad del País Vasco / Euskal Herriko Univertsitatea

Alameda Urquijo, s/n. 48013 Bilbao, Spain ricardolopezrobles@outlook.com

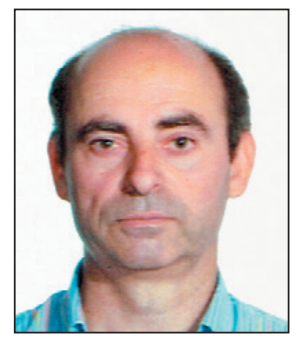

\section{José-Ramón Otegi-Olaso}

http://orcid.org/0000-0001-6023-8537

Universidad del País Vasco / Euskal Herriko Univertsitatea

Alameda Urquijo, s/n. 48013 Bilbao, Spain joserra.otegi@ehu.eus

\section{Abstract}

The current research conducts a bibliometric performance and intellectual structure analysis of El profesional de la información (EPI) from 2006 to 2017. On the one hand, the EPI's performance is analyzed according to the data retrieved from the database Social Sciences Citation Index (SSCl), part of Web of Science Core Collection, putting the focus on the productivity of the authors, number of references, organizations, countries and main publications. On the other hand, the intellectual structure of the journal is analyzed with SciMAT, an open source (GPLV3) bibliometric software tool developed to perform a science mapping analysis under a longitudinal framework, identifying the main thematic areas that have been the object of research, their composition, relationship and evolution during the period analyzed.

\section{Keywords}

Academic journals; Bibliometrics; Authorship; Citations; Thematic analysis; Co-word analysis; Keywords analysis; Conceptual evolution map; Science mapping analysis; Library and Information Science; Communication; SciMAT; Web of Science; WoS; El profesional de la información.

\section{Financing}

This article is part of the work of the consolidated research group Cultura i Continguts Digitals, ref. 2017 SGR422.

\section{Acknowledgments}

The authors José-Ricardo López-Robles and Nadia-Karina Gamboa-Rosales acknowledge the support by the Conacyt-Consejo Nacional de Ciencia y Tecnología (Mexico) and DGRI-Dirección General de Relaciones Exteriores (México) to carry out this study. 


\section{Introduction}

It is well known that scientific journals constitute one of the main channels of communication to expose the results of scientific projects and research, which results in both the visibility of the authors and the participating organizations and, for this reason, they have become a key instrument to evaluate these researchers and organizations in respect of their knowledge field (Abadal, 2017; López-Ornelas; Cordero-Arroyo, 2005). Consequently, scientific journals are a priority object of study in bibliometric research (Callon; Courtial; Penan, 1995; Castillo-Esparcia; Rubio-Moraga; Almansa-Martínez, 2012).

In research whose object of study is the academic journals, three different approaches can be found:

1) Bibliometric performance analysis of authorship and production: they focus on analyzing the authors profiles according to elements such as affiliation, country, production and the production of articles, examining which are the most cited or relevant;

2) Bibliometric thematic analysis: they focus on addressing the main themes discussed, as well as their relationships or evolution;

3) Research methodology studies: these focus on the research methods and techniques used to develop the publications in journals.

There are publications that address one of these approaches (i.e. about the first approach Calderón-Garrido; Gustems-Carnicer (2018), López-Robles et al. (2019); two of them, the thematic analysis and research methodology by Guallar et al. (2017); López-Robles et al. (2018b); or all of them (Ferran-Ferrer et al., 2017; López-Robles et al., 2018a).

This article is placed in the second group, addressing the first and second approaches, this means, a bibliometric analysis of authorship and production and thematic analysis, with the particularity that it covers year by year the evolution of both approaches.

From another perspective, we can also find other different approaches:

1) Research that analyzes several journals or a significant group of them within a discipline or knowledge areas (Delgado-López-Cózar, 2001; Somoza et al., 2017; Goyanes; Rodríguez-Gómez; Rosique-Cedillo, 2018).

2) Research focused on the in-depth analysis of a single publication, usually dealing with its evolution over a specific period of time, as an example, in the area of Library and Information Science: González-Alcaide; Gorraiz; Hervás-Oliver, 2018; Abadal, 2018; Arquero-Avilés; Del-Río-Sadornil, 2002; Pérez-Álvarez-Ossorio, 1997; López-López et al., 2001.

The present article is placed in this second group of studies that deal with the analysis of a unique journal over a period of time. El profesional de la información (hereinafter EPI) is the journal chosen for the analysis. It has a highly relevant role in its area of knowledge, although it has not been the object of an exclusive bibliometric analysis covering a period of time, with the partial exception of the study by Ardanuy and Urbano (2017), which analyzes the journal authorship in comparison with a local congress, justifying the opportunity of this research.

Therefore, the aim of this article is to evaluate the EPI evolution from 2006 to 2017 by conducting a bibliometric analysis of authorship and production, emphasizing the identification of the main research themes, their relationship and main components. In addition, a longitudinal evolution map is presented year by year that groups the identified research themes according to thematic areas, establishing a reference framework for researchers and future research.

\section{Methodology and data preparation}

\subsection{Methodology}

This article is framed within the field of bibliometrics (Glenisson et al., 2005; Moed, 2009) and shows a longitudinal study which takes the case study as a research technique. In addition, it applies specific techniques of bibliometric studies, which are outlined below (Ferran-Ferrer et al., 2017).

The bibliometric approach has been based on two drivers:

- The performance indicators analysis, evaluating the impact of authors and publications, as well as their evolution;

- The scientific map of the journal, representing in a space the relationship between publications and themes, which allows to visualize, to understand and to discover hidden connections between themes of interest for the development a specific scientific field (Cobo et al., 2011b).

For this purpose, SciMAT has been used, which in comparison to other bibliometric software (Cobo et al., 2012), it has been used to evaluate:

- The performance of a specific thematic or knowledge area (Alcaide-Muñoz et al., 2017; Cobo et al., 2014; López-Robles et al., 2018c); 
- A set of publications (López-Robles et al., 2019; Moral-Muñoz et al., 2016; Perez-Cabezas et al., 2018);

- A journal.

The application of SciMAT under last-mentioned approach has been addressed in the literature in different forms:

- In the first case, we find an analysis in which the strategic diagrams group periods of time longer than one year, and it does not include a conceptual evolution map (Cobo et al., 2015);

- In the second case, we find an analysis in which the strategic diagrams group periods of time longer than one year, and it includes a conceptual evolution map (Cobo et al., 2018; López-Herrera et al., 2012);

- In the latter case, we find an analysis in which the strategic diagrams group periods of one year each, and it includes a conceptual evolution map (López-Robles et al., 2018a).

The latter variant hardly appears in the literature, and the publication cited above hardly evaluates a few publications in a short period of time. For this reason, this case has been selected to develop a complete analysis of EPI, a journal with a trajectory and a production considerably superior.

To that end, firstly, the journal's publications and their bibliographic information available in the database Social Sciences Citation Index ( $\mathrm{SSCl}$ ), part of Web of Science Core Collection, have been compiled and analyzed. Furthermore, the h-index and $\mathrm{H}$-Classics indexes have been applied to them. Secondly, the strategic diagrams and conceptual evolution map were developed using SciMAT, a software tool developed to perform a science mapping analysis. It is explained in more detail below.

On the one hand, the information available in $\mathrm{SSCl}$ facilitates the analysis of the main performance indicators: productivity of authors in terms of publications and citations, agents and countries. This part of the analysis has been complemented using the h-index and H-Classics indexes (Alonso et al., 2009; Hirsch, 2005; Martínez et al., 2014; Schreiber, 2007; Schubert, 2007). Firstly, the h-index has been applied, it allows to measure both the productivity and the impact of a set of publications, linking the number of publications and their citations. Then, the H-Classics has been applied, which is used as an impartial criterion to systematize the searching process through the $h$-index. The combination of both indexes reduces the discrepancy that may exist between the most cited publications and those that have not yet reached the same level, establishing a common reference point for publications within a specific knowledge area.

On the other hand, the main research themes within the EPI were identified and displayed as a strategic map using SciMAT (Cobo et al., 2012), it facilitates the implementation of a four-stage methodology:

- Detection of research themes (Powell et al., 2016);

- Visualization of research themes and their thematic networks (Callon; Courtial; Laville, 1991; He, 1999);

- Discovery of thematic areas (Sternitzke; Bergmann, 2009);

- Performance analysis (Cobo et al., 2012).

Science maps allow to clearly visualize the evolution of a journal, delimiting research areas and its development, capturing its conceptual and cognitive structure (Cobo et al., 2011a). Prior to the performance of the science map, each period is characterized as a thematic network and it is represented as a set of themes classified and positioned in a plane divided into four categories, called a strategic diagram (see figure 1a).

Thematic networks are structured according to the frequency of co-occurrence of keywords and are grouped using the algorithm of simple centers, one of the best known in the literature and used for co-word analysis. In addition, this algorithm returns groups tagged with the label of the most central node; it means, from the group of keywords the most relevant label groups the rest of labels according to its relations and importance. When the bibliometric network of co-words is completed, the similitude is calculated from the co-occurrence of the keywords identified in the set of publications. As a result, a set of keyword groups and their connections are identified, these groups are called themes, and are classified into four categories, according to Callon's centrality and density:

- Motor themes (Q1, upper-right quadrant): These themes are both well developed and important for the structure of the research field;

- Peripheral themes (Q2, upper-left quadrant): well-developed internal ties but unimportant external ties and so, they have a marginal role for the development of the scientific field;

- Emerging or declining themes (Q3, lower-left quadrant): They are both weakly developed and marginal;

- Basic and transversal themes (Q4, lower-left quadrant): They are important for a research field but are not developed.

It is important to mention that the motor themes and the basic and transversal themes are considered as those that favor the development and consolidation of a field of knowledge or a journal due to their density and centrality.

This is followed by the scientific map (see figure 1b), which lists each strategic diagram and relates its evolution over time. This map is classified by thematic areas
We obtain keyword groups and their interconnections. These groups are called themes, and are classified into four categories: Motor themes, Peripheral themes, Emerging or declining themes, and Basic and transversal themes 


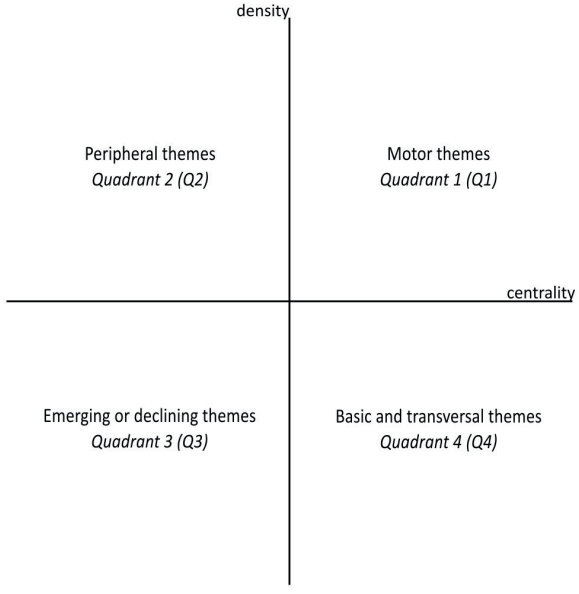

(a)

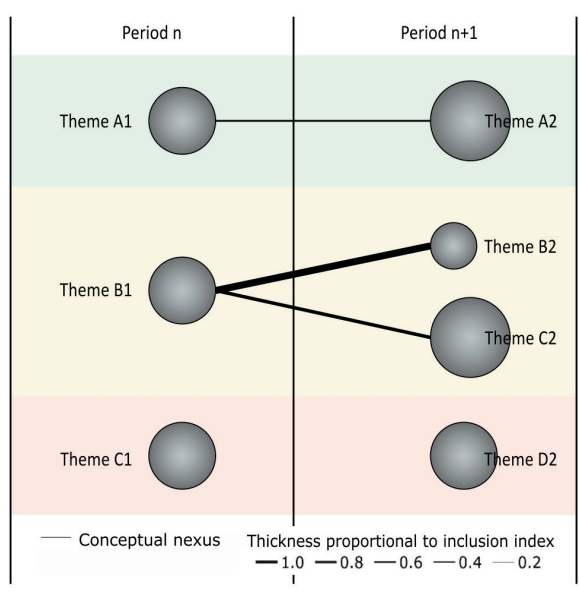

(b)

Figure 1. (a) Strategic diagram and (b) Thematic evolution

to facilitate its analysis and the relationship between different areas of research, including within a time frame the changes in the conceptual, social and intellectual structure, based on the available bibliographic information and its main bibliometric indicators (Cobo, 2012).

\subsection{Dataset}

As mentioned before, EPI publications available on the Web of Science (WoS) were retrieved. To do that, the advanced query used on the Social Sciences Citation Index (SSCI) was its ISSN: IS= "1386-6710".

This query retrieved a total of 1,078 publications, of which 1,038 were for the period 2006-2017. In addition, citations of these publications were also analyzed; they were counted up to 9th June 2018.

The publications identified in SSCl were downloaded as plain text and imported into SciMAT software to build the knowledge base for science mapping analysis. Thus, the bibliographic information stored by SSCI (affiliations, authors, references, date of publication, keywords and citations obtained, mainly) is available for each publication, which allows to analyze the data, identify relationships and, consequently, obtain better results in the analysis of the science map.

In addition, in order to improve and guarantee the quality of the data, a revision process was applied. It analyses and merges the concepts that have the same meaning or that represent the same subject (for example: "Knowledge Management", "Knowledge-Management" and "KM" were grouped as “KNOWLEDGE-MANAGEMENT-(KM)").

As a next step, the SciMAT period manager was used to avoid data flatness. The best approach when analyzing the evolution of the data is to evaluate them year by year, but sometimes it is advisable to group them in periods in order to generate a sufficient mass of publications for analysis. In this case, it has been decided to carry out an analysis year by year, so this study comprises twelve periods from 2006 to 2017.

\section{Performance bibliometric analysis (authorship and production)}

\subsection{Presentation of the journal}

El profesional de la información (EPI) is defined on its website as

"a journal on communication, information, indicators, libraries and information technologies".

http://www.elprofesionaldelainformacion.com/presentacion.html

In thematic terms, EPI proposes to the scientific community a main topic for each issue, calling for contributions about it (call for papers). However, each issue could include publications that cover other topics and that the authors send independently of the previous calls.

There are some facts about EPI's evolution that can be highlighted. It was born in 1992 initially with the name of Information world en español. It's not until 1999 when it adopts its current name. Since 2002 it has been published bimonthly and since 2009 it appears in the WoS Journal Citation Reports (JCR) in the Information Science \& Library Science category, also entering in January 2019 in the WoS Communication category (El profesional de la información, n.d.).

Table 1 shows the evolution during the analysis period of this research (2006-2017) of the Journal Citation Reports (JCR) indexes of Web of Science and SCImago Journal \& Country Rank (SJR) of Scopus, the analysis period of this research. 
Table 1. EPI's evolution in JCR (WoS) and SJR (Scopus) 2006-2017

\begin{tabular}{|c|c|c|c|c|c|}
\hline \multirow{2}{*}{ Year } & \multirow{2}{*}{$\begin{array}{c}\text { InCites Journal } \\
\text { Citation Reports } \\
\text { Information Science } \\
\text { \& Library Science }\end{array}$} & \multicolumn{4}{|c|}{ SCImago Journal \& Country Rank } \\
\hline & & $S J R$ & Communication & Information Systems & $\begin{array}{c}\text { Library and } \\
\text { Information Sciences }\end{array}$ \\
\hline 2006 & - & - & - & - & - \\
\hline 2007 & - & 0.163 & Q3 & Q4 & Q3 \\
\hline 2008 & $0.400(\mathrm{Q} 3)$ & 0.198 & Q3 & Q3 & Q3 \\
\hline 2009 & $0.478(\mathrm{Q} 3)$ & 0.254 & Q3 & Q3 & Q3 \\
\hline 2010 & $0.375(\mathrm{Q} 3)$ & 0.277 & Q2 & Q3 & Q3 \\
\hline 2011 & $0.326(\mathrm{Q} 3)$ & 0.271 & Q2 & Q3 & Q3 \\
\hline 2012 & $0.439(\mathrm{Q} 3)$ & 0.317 & Q2 & Q3 & Q3 \\
\hline 2013 & $0.402(\mathrm{Q} 3)$ & 0.379 & Q2 & Q3 & Q2 \\
\hline 2014 & $0.356(\mathrm{Q} 4)$ & 0.458 & Q2 & Q2 & Q2 \\
\hline 2015 & $0.710(\mathrm{Q} 3)$ & 0.433 & Q2 & Q2 & Q2 \\
\hline 2016 & $1.063(\mathrm{Q} 3)$ & 0.549 & Q2 & Q2 & Q1 \\
\hline 2017 & $1.318(\mathrm{Q} 2)$ & 0.652 & Q1 & Q2 & Q1 \\
\hline
\end{tabular}

EPI has the participation of 1,448 researchers from 436 organizations and 32 countries. In terms of countries, Spain concentrates $80 \%$ of the journal's publications and excluding Spain, United Kingdom, Argentina, United States, Mexico, Colombia and Chile are in the group of the most productive countries. These countries highlight for their constant activity over time, with percentages of publications each between $1 \%$ and $2 \%$ of the total.

Consequently, the analysis of the journal in terms of publications, authorship, citations and their impact is presented below. The indicators analyzed were: number of publications, citations received, most productive authors, most cited publications, geographical distribution and most productive organizations. The analysis is structured in three parts:

- Publications and citations;

- Most productive and cited authors, geographical distribution and organizations;

- Most cited publications.

\subsection{Publications and citations}

In January 2006 EPI begins to be indexed in the Social Sciences Citation Index database of the Web of Science and it appears in the Journal Citation Reports (JCR) corresponding to 2009 for the first time in June 2010, with an Impact Factor of 0.475 . During that time, it has maintained a constant publication activity and it has increased the number of publications, recording two historical maximums in the last two periods analyzed: 95 and 115 publications, in 2016 and 2017 respectively. Table 2 and Figure 2 show the EPI publications in the Web of Science Core Collection and distribution of publications by year (1988-2017) for the period analyzed, respectively.

Figure 3 shows the distribution of citations per year for the defined periods. Similar to the case of the publications, the citation distribution showed a positive developmental trend during 2006-2017. During this period, a total of 2,585 citations (including self-citations) were recorded, and the total number of quotations (cited references) not including self-citations is 1,776 . Finally, the Web of Science indicates that the average citation per cited article is 2.49 .

Table 2. EPI publications in the Social Sciences Citation Index

\begin{tabular}{|l|c|c|}
\hline \multirow{2}{*}{\multicolumn{1}{c|}{ Type }} & \multicolumn{2}{c|}{ Publications (N = 1,038) } \\
\cline { 2 - 3 } & $\mathbf{n}$ & \% \\
\hline Articles & 926 & 89.21 \\
\hline Editorial material & 79 & 7.61 \\
\hline Book reviews & 18 & 1.73 \\
\hline Review & 9 & 0.87 \\
\hline Revision of software or database & 6 & 0.58 \\
\hline
\end{tabular}

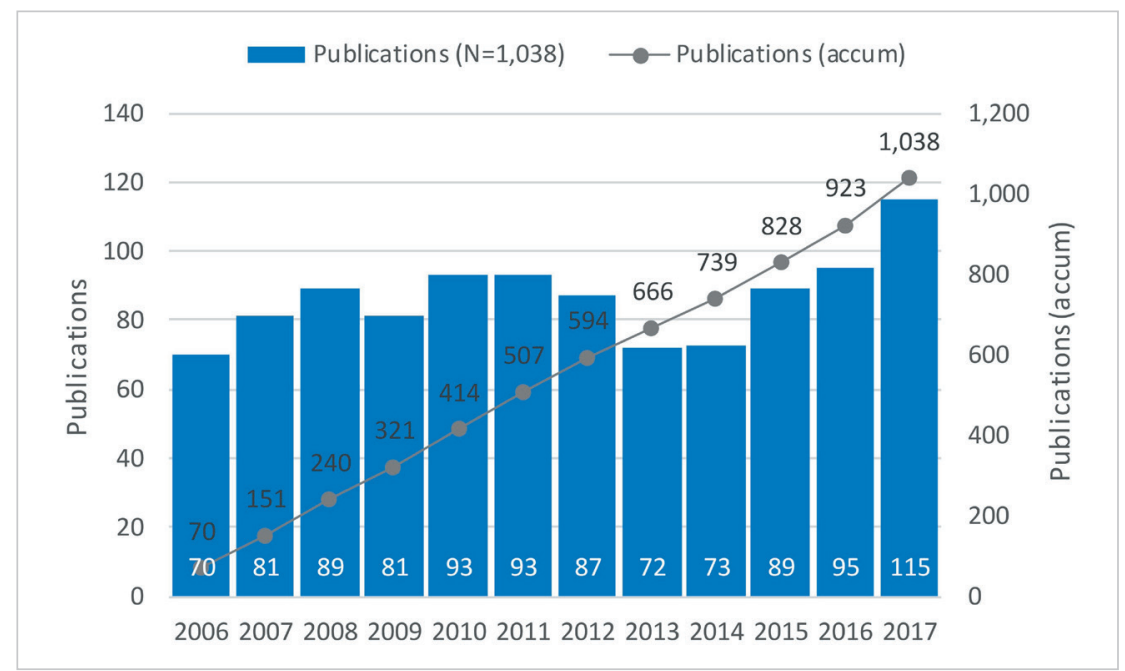

Figure 2. EPI distribution of publications by year (1988-2017) 
Taking into account the evolution in terms of citations observed in Figure 3, it can be assumed that this positive trend will continue in the coming years. However, it should be noted that the citations collected in the last two periods show a trend towards fictitious decline; according to Wang (2013), the most cited publications are generally those that occupy previous years due to the time span between publication and reference. It is estimated that a publication needs between 3 and 7 years to reach its highest number of citations.

\subsection{Most productive and cited authors, geographical distribu- tion and organizations}

Table 3 shows the most productive authors for the period 20062017 and Table 4 shows the most productive authors year to year. The data is arranged in descending order, and when was a tie between various authors; all of them have been included in alphabetical order. This criterion is applied to all tables included in this article.

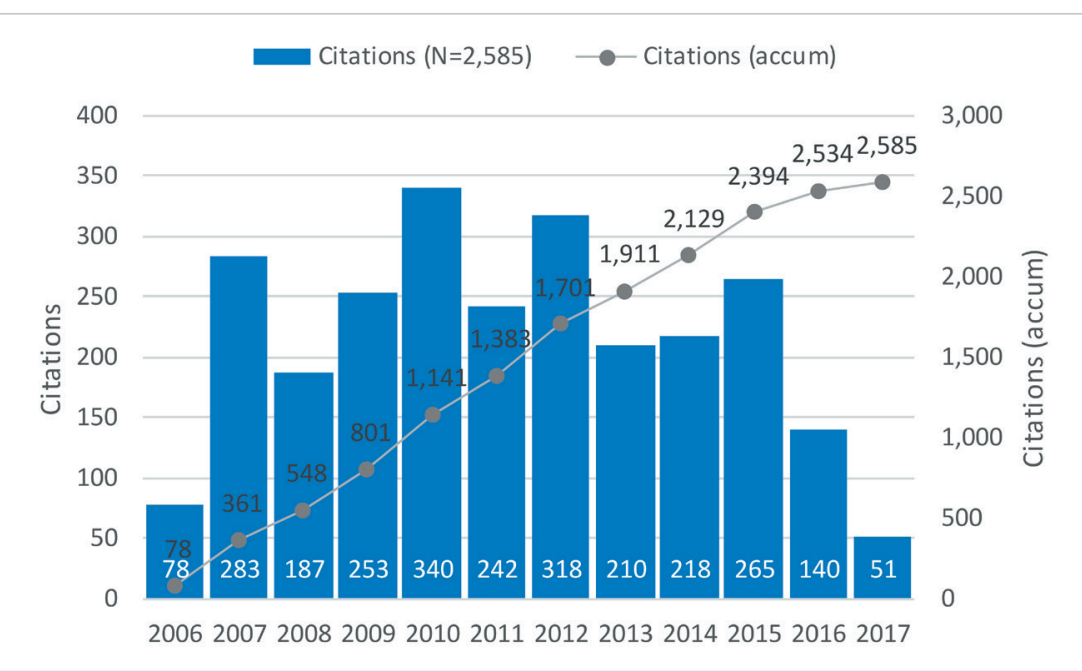

Figure 3. EPI distribution of citations by year (2006-2017)

Table 3. Most productive authors from 2006 to 2017

\begin{tabular}{|c|c|l|}
\hline \multicolumn{2}{|c|}{$\begin{array}{c}\text { Publications } \\
\text { (N=1,038) }\end{array}$} & \multirow{2}{*}{ Authors } \\
\cline { 1 - 2 }$n$ & $\%$ & \\
\cline { 1 - 2 } 28 & 2.70 & Codina \\
\hline 22 & 2.12 & Torres-Salinas \\
\hline 17 & 1.64 & Guallar \\
\hline 15 & 1.45 & Peset \\
\hline 14 & 1.35 & Delgado-López-Cózar \\
\hline 13 & 1.25 & Ferrer-Sapena; Marcos \\
\hline 12 & 1.16 & Pérez-Montoro \\
\hline 11 & 1.06 & Rovira \\
\hline 10 & 0.96 & Abadal \\
\hline 9 & 0.87 & Baiget; Eíto-Brun; Jiménez-Contreras; Rodríguez-Gairín \\
\hline
\end{tabular}

Table 4. Most productive authors by year

\begin{tabular}{|c|c|}
\hline Year & (Publications) Authors ( $N=1,038)$ \\
\hline 2006 & (4) Marcos; (3) Baiget; (2) Aguillo; Delgado-López-Cózar; Herrero-Solana; Ortega \\
\hline 2007 & $\begin{array}{l}\text { (9) Codina; (4) Monistrol; (3) Baiget; Ferrer-Sapena; (2) Marcos; Ortega; Peset; Rodríguez-Gairín; Rovira; Sánchez-Jiménez; SCImago; } \\
\text { Torres-Salinas; Vives-Gracia }\end{array}$ \\
\hline 2008 & $\begin{array}{l}\text { (5) Ferrer-Sapena; (4) De-Moya-Anegón; Peset; (3) Codina; Delgado-López-Cózar; Eíto-Brun; Redondo; (2) Carrato-Mena; Guallar; La- } \\
\text { ra-Navarra; Ribera; Torres-Salinas }\end{array}$ \\
\hline 2009 & $\begin{array}{l}\text { (5) Delgado-López-Cózar; Torres-Salinas; (3) Codina; Guallar; Ruiz-Pérez; (2) Caldera-Serrano; Hernández-García; Iglesias-Pradas; Jimé- } \\
\text { nez-Contreras; Lloret-Romero; Merlo-Vega; Orduña-Malea; Ros-Martín; Serrano-Cobos }\end{array}$ \\
\hline 2010 & $\begin{array}{l}\text { (5) Marcos-Recio; Sánchez-Vigil; (3) Codina; Guallar; Marcos; Micó-Sanz; Olivera-Zaldúa; Rovira; Torres-Salinas; (2) Aleixandre-Benavent; } \\
\text { Cordón-García; Díaz-Noci; García; Giménez-Toledo; Gómez-Barroso; Jiménez-Contreras; Jiménez-Fernández; Masip; Nuño-Moral; Pe- } \\
\text { draza-Jiménez; Pérez-Montoro; Peset; Rodríguez-Parada; Salaverría }\end{array}$ \\
\hline 2011 & $\begin{array}{l}\text { (2) Barra; Codina; D’Alòs-Moner; Delgado-López-Cózar; Ferrer-Sapena; Fumero-Reverón; García-Marco; García-Moreno-Torres; Giralt; } \\
\text { Herrera; Moreiro; Peset; Rodríguez-Gairín; Said-Hung; Sánchez-Vigil; Somoza-Fernández; Torres-Salinas; Xifra }\end{array}$ \\
\hline 2012 & $\begin{array}{l}\text { (3) Abadal; Gonzales-Aguilar; Ramírez-Posada; (2) Anglada; Cabezas-Clavijo; Guallar; Hilera-González; Ivars-Nicolás; Ruiz-lbáñez; To- } \\
\text { rres-Salinas }\end{array}$ \\
\hline 2013 & (2) Aguilar-Moreno; Codina; Granell-Canut; Peset; Rausell-Koster; Saorín \\
\hline 2014 & (3) Torres-Salinas; (2) Anglada; Jiménez-Contreras; López-de-Solís; Pérez-Montoro; Robinson-García \\
\hline 2015 & $\begin{array}{l}\text { (3) Kousha; Thelwall; (2) Giménez-Toledo; González-Fernández-Villavicencio; González-Teruel; Mañana-Rodríguez; Salaverría; Sturges; } \\
\text { Tejada-Artigas; Yubero }\end{array}$ \\
\hline 2016 & $\begin{array}{l}\text { (3) Martínez-Fernández; Pérez-Montoro; (2) Aguilar-Paredes; Aguillo; Arcila-Calderón; Campos-Freire; Codina; Gómez-Domínguez; Her- } \\
\text { nández-Pérez; López-García; Martín-Martín; Masip; Orduña-Malea; Quintas-Froufe; Rodríguez-Vázquez; Rúas-Araújo; Sánchez-Gómez; } \\
\text { Thelwall }\end{array}$ \\
\hline 2017 & $\begin{array}{l}\text { (2) Carratalá; Casero-Ripollés; Codina; Ferran-Ferrer; López-Meri; Manfredi-Sánchez; Martínez-Rolán; Merlo-Vega; Ortega-Mohedano; } \\
\text { Palau-Sampio; Pérez-Montoro }\end{array}$ \\
\hline
\end{tabular}


The most cited authors during the period 20062017 are shown in Table 5, and the most cited for each year are shown in Table 6.

Bearing in mind the findings of Tables 3, 4, 5 and 6 , it is important to highlight that several of the main authors of Table 3 coincide with Table 5, thus, reflecting a congruence between quantity and quality (impact) of the journal's publications. It can be specified that among the most cited authors (Table 5) there are not only several of the main authors in terms of production (Table 3), such as Codina, Torres-Salinas, Delgado-López-Cózar, Guallar, Peset, Abadal and Jiménez-Contreras, but similarly, other authors with fewer articles but who have obtained a relevant impact, such as Casero-Ripollés, Leydesdorff, Thelwall, Kousha, Aleixandre-Benavent, Pedraza-Jiménez and Díaz-Noci.
Table 5. Most cited authors from 2006 to 2017

\begin{tabular}{|c|c|l|}
\hline \multicolumn{2}{|c|}{ Cites $(\mathbf{N}=\mathbf{2 , 5 8 5})$} & \multicolumn{2}{|}{ Authors } \\
\cline { 1 - 2 } $\mathbf{n}$ & $\%$ & \\
\cline { 1 - 2 } 181 & 7.00 & Torres-Salinas \\
\hline 155 & 5.99 & Delgado-López-Cózar \\
\hline 107 & 4.14 & Guallar \\
\hline 84 & 3.25 & Codina \\
\hline 68 & 2.63 & Leydesdorff; Peset \\
\hline 66 & 2.55 & Ferrer-Sapena \\
\hline 65 & 2.51 & Casero-Ripollés \\
\hline 63 & 2.44 & Abadal; Thelwall \\
\hline 61 & 2.35 & Kousha \\
\hline 56 & 2.18 & Aleixandre-Benavent; Jiménez-Contreras \\
\hline
\end{tabular}

Table 6. Most cited authors by year

\begin{tabular}{|c|c|}
\hline Year & (Cites) Authors $(\mathrm{N}=\mathbf{2 , 5 8 5})$ \\
\hline 2006 & (7) Ortega; Picazo; Tramullas; (6) Bonet; Fernández-Quijada; (5) Marcos \\
\hline 2007 & (37) Aleixandre-Benavent; González-Alcaide; Valderrama-Zurián; (21) Ortega; (18) Bordons; Costas \\
\hline 2008 & (16) De-Moya-Anegón; Ferrer-Sapena; (14) De-Nooy; Leydesdorff; Schank; Scharnhorst; (13) Peset \\
\hline 2009 & (61) Delgado-López-Cózar; (56) Torres-Salinas; (31) Guallar \\
\hline 2010 & (44) Torres-Salinas; (43) Díaz-Noci; (42) Casero-Ripollés \\
\hline 2011 & (34) Ferrer-Sapena; Peset; (28) Delgado-López-Cózar; García-Moreno-Torres; Herrera; Torres-Salinas; (25) Said-Hung \\
\hline 2012 & (24) Abadal; (19) Leydesdorff; (17) Greenberg; Méndez \\
\hline 2013 & (27) Adams; Leydesdorff; Park; Wagner; (19) Jeremic; Jovanovic-Milenkovic; Martic; Radojicic; (12) Giménez-Toledo; Rodríguez-Yunta \\
\hline 2014 & (26) Torres-Salinas; (21) Costas; Robinson-García; Zahedi; (19) Anglada \\
\hline 2015 & (61) Kousha; (61) Thelwall; (18) Salaverría; (15) Campos-Freire \\
\hline 2016 & (16) Delgado-López-Cózar; Martín-Martín; Orduña-Malea; (11) Beltrán-Orenes; Martínez-Pastor \\
\hline 2017 & $\begin{array}{l}\text { (9) Casero-Ripollés; (3) De-Frutos-Torres; Fuente-Cobo; Marcos-Santos; Rebolledo; Rodríguez-Virgili; Rom-Rodríguez; Vilajoana-Alejan- } \\
\text { dre; Zamora-Medina; (2) Aguado; Boeykens; Delgado; Ferran-Ferrer; Manfredi-Sánchez; Martínez-Martínez; Molina-Rodríguez-Navas; } \\
\text { Monteagudo-Barandalla; Moreno-Sardà; Navarro; Prado; Simelio-Solà; Torrecillas-Lacave; Vázquez-Barrio }\end{array}$ \\
\hline
\end{tabular}

In terms of internationalization, in regard to languages, the EPI publishes both in Spanish and English. Spanish is the main language used with $87.77 \%$ (911) followed by English with $12.14 \%$ (126) (it should be highlight that among the latter there are several non-Spanish authors, and they have gained presence in recent years in the journal). Table 7 shows the most productive countries from 2006 to 2017.

Table 8 presents the most productive Spanish and foreign organizations from 2006 to 2017.

It can be observed that the most productive organizations in EPI are Universitat de Barcelona, Universitat Pompeu Fabra and Universidad de Granada, followed by Universidad Carlos III de Madrid, Universidad Complutense de Madrid, Universidad Politécnica de Valencia and Universidad de Navarra. The most productive organizations outside Spain are University of Amsterdam (Netherlands), Universidad de Antioquia (Colombia), Max Planck Gesellschaft (Germany), Universidad Nacional Autónoma de México (Mexico) and University of Wolverhampton (United Kingdom).

Table 7. Most productive countries from 2006 to 2017

\begin{tabular}{|l|c|c|}
\hline \multirow{2}{*}{\multicolumn{1}{c}{ Countries }} & \multicolumn{2}{c|}{ Publications (N = 1,038) } \\
\cline { 2 - 3 } & $\mathbf{n}$ & $\%$ \\
\hline Spain & 838 & 80.73 \\
\hline United Kingdom & 21 & 2.02 \\
\hline Argentina; United States & 18 & 1.73 \\
\hline Mexico & 15 & 1.45 \\
\hline Colombia & 14 & 1.35 \\
\hline Chile & 10 & 0.96 \\
\hline Netherlands; Portugal & 9 & 0.87 \\
\hline Germany; Brazil & 8 & 0.77 \\
\hline Cuba & 7 & 0.67 \\
\hline Italy & 6 & 0.58 \\
\hline
\end{tabular}


Table 8. Most productive Spanish and foreign organizations from 2006 to 2017

\begin{tabular}{|c|c|}
\hline $\begin{array}{l}\text { Publications } \\
(\mathrm{N}=1,038)\end{array}$ & Spanish organizations \\
\hline 71 & Universitat de Barcelona \\
\hline 68 & Universitat Pompeu Fabra \\
\hline 60 & Universidad de Granada \\
\hline 58 & Universidad Carlos III de Madrid \\
\hline 56 & Universidad Complutense de Madrid \\
\hline 43 & Universidad Politécnica de Valencia \\
\hline 35 & Universidad de Navarra \\
\hline 29 & $\begin{array}{l}\text { Consejo Superior de Investigaciones Científicas; Universitat Oberta de Catalunya; Universidad de Salamanca; Universidad de } \\
\text { Valencia }\end{array}$ \\
\hline 22 & Universidad de Zaragoza \\
\hline \multirow[t]{2}{*}{21} & Universitat Autònoma de Barcelona; Universidad Rey Juan Carlos \\
\hline & Foreign organizations \\
\hline 6 & University of Amsterdam (Netherlands); Universidad de Antioquia (Colombia) \\
\hline 5 & $\begin{array}{l}\text { Universidad Nacional Autónoma de México (Mexico); University of Wolverhampton (United Kingdom); Max Planck Gesellschaft } \\
\text { (Germany) }\end{array}$ \\
\hline 4 & Université Paul Valéry Montpellier 3 (France) \\
\hline 3 & $\begin{array}{l}\text { Universidad Nacional de Córdoba (Argentina); Loughborough University (United Kingdom); Université Catholique de Louvain } \\
\text { (Belgium) }\end{array}$ \\
\hline 2 & $\begin{array}{l}\text { Long Island University (United States); Universidad Nacional de la Plata (Argentina); Novosibirsk State University (Russia); Ponti- } \\
\text { ficia Universidad Católica de Chile (Chile); Universidad Autónoma de Occidente (Colombia); Universidade da Beira Interior (Portu- } \\
\text { gal); University of Belgrade (Serbia); Universidad Católica Andrés Bello (Venezuela); Universidade de Coimbra (Portugal); Universi- } \\
\text { dad Estatal de Milagro (Ecuador); Universidade Federal de Santa Catarina (Brazil); Universidad de La Habana (Cuba); Universidad } \\
\text { del Norte (Colombia); Universidad de Piura (Peru); Universidad de Playa Ancha (Colombia) }\end{array}$ \\
\hline
\end{tabular}

\subsection{Analysis of most cited publications}

In order to analyze the most cited publications, a two-fold approach is proposed based on h-index (Hirsch, 2005) and H-Classics (Martínez et al., 2014), respectively. To this end, the search query used in the database Social Sciences Citation Index has an h-index of 18 . Using the value of $h$-index as a reference, the relevant publications have been identified and are listed in their original language of publication in Table 9. This list includes authorship information, type of publication (article refers to research paper published in the Articles or Analysis sections; Editorial refers to texts published in the Observatory section) and the number of citations registered in WoS. Figure 4 shows the distribution of the most cited publications for the period analyzed.

In the same way as the distribution of publications, the distribution of citations shows a positive trend in the period 2006 2017. During this period, a total of 15 articles and 3 editorials were recorded, which include 428 citations (including self-citations) and 422 citations excluding self-citations. In addition, according to the SSCI database, the average number of citations per article is 23.78. Finally, it can be observed that there are articles that were kept for reference after the seven-year period, suggesting that these publications are part of EPI's core (Wang, 2013).

Table 10 shows the authors with the highest number of most cited publications and Table 11 shows the countries from these authors are originate.
The most productive organizations in EPI are the Spanish universities of Barcelona, Pompeu Fabra and Granada, followed by Carlos III, Complutense de Madrid, Politécnica de Valencia and Navarra

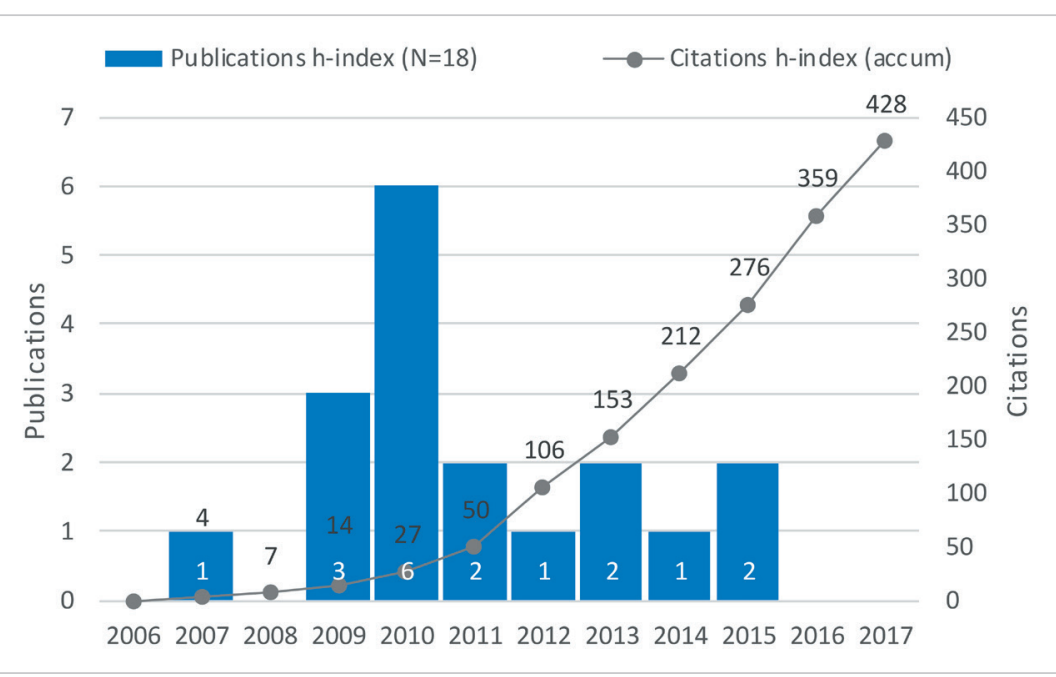

Figure 4. Distribution of most relevant publications by year 
Table 9. H-classics of EPI

\begin{tabular}{|c|c|c|c|c|}
\hline Rank & Title (author/s, year of publication) & $\begin{array}{l}\text { First author affiliation } \\
\text { (country) }\end{array}$ & Type & Cites \\
\hline 1 & $\begin{array}{l}\text { "Prensa en internet: nuevos modelos de negocio en el escenario de la conver- } \\
\text { gencia" (Casero-Ripollés, 2010) }\end{array}$ & Universitat Jaume I (Spain) & Article & 42 \\
\hline 2 & $\begin{array}{l}\text { "El factor de impacto de las revistas científicas: limitaciones e indicadores alterna- } \\
\text { tivos" (Aleixandre-Benavent; Valderrama-Zurián; González-Alcaide, 2007) }\end{array}$ & Universidad de Valencia (Spain) & Editorial & 37 \\
\hline 3 & $\begin{array}{l}\text { "Cibermedios y web 2.0: modelo de análisis y resultados de aplicación" (Rodrí- } \\
\text { guez-Martínez; Codina; Pedraza-Jiménez, 2010) }\end{array}$ & $\begin{array}{l}\text { Universitat Pompeu Fabra } \\
\text { (Spain) }\end{array}$ & Article & 28 \\
\hline 4 & $\begin{array}{l}\text { "International collaboration in science: The global map and the network" (Ley- } \\
\text { desdorff; Wagner; Park; Adams, 2013) }\end{array}$ & $\begin{array}{l}\text { University of Amsterdam (Ne- } \\
\text { therlands) }\end{array}$ & Article & 27 \\
\hline 5 & $\begin{array}{l}\text { "Evaluación de hemerotecas de prensa digital: indicadores y ejemplos de buenas } \\
\text { prácticas" (Guallar; Abadal, 2009) }\end{array}$ & $\begin{array}{l}\text { Universitat de Barcelona } \\
\text { (Spain) }\end{array}$ & Article & 26 \\
\hline 6 & $\begin{array}{l}\text { "Web indicators for research evaluation. Part 1: Citations and links to academic } \\
\text { articles from the Web" (Thelwall; Kousha, 2015) }\end{array}$ & $\begin{array}{l}\text { University of Wolverhampton } \\
\text { (United Kingdom) }\end{array}$ & Article & 23 \\
\hline 7 & $\begin{array}{l}\text { "Open data y Linked open data: su impacto en el área de bibliotecas y documen- } \\
\text { tación" (Peset; Ferrer-Sapena; Subirats-Coll, 2011) }\end{array}$ & $\begin{array}{l}\text { Universidad Politécnica de } \\
\text { Valencia (Spain) }\end{array}$ & Article & 23 \\
\hline 8 & $\begin{array}{l}\text { "Web indicators for research evaluation. Part 2: Social media metrics" (Thelwall; } \\
\text { Kousha, 2015) }\end{array}$ & $\begin{array}{l}\text { University of Wolverhampton } \\
\text { (United Kingdom) }\end{array}$ & Article & 22 \\
\hline 9 & $\begin{array}{l}\text { "Investigación internacional sobre ciberperiodismo: hipertexto, interactividad, } \\
\text { multimedia y convergencia" (Masip; Díaz-Noci; Domingo; Micó-Sanz; Salaverría, } \\
\text { 2010) }\end{array}$ & Universitat Ramon Llull (Spain) & Article & 22 \\
\hline 10 & $\begin{array}{l}\text { "Clasificación integrada de revistas científicas (CIRC): propuesta de categorización } \\
\text { de las revistas en ciencias sociales y humanas" (Torres-Salinas; Bordons; Gimé- } \\
\text { nez-Toledo; Delgado-López-Cózar; Jiménez-Contreras; Sanz-Casado, 2010) }\end{array}$ & $\begin{array}{l}\text { Universidad de Granada y Uni- } \\
\text { versidad de Navarra (Spain) }\end{array}$ & Article & 22 \\
\hline 11 & $\begin{array}{l}\text { "New data, new possibilities: Exploring the insides of Altmetric.com" (Robin- } \\
\text { son-García; Torres-Salinas; Zahedi; Costas, 2014) }\end{array}$ & $\begin{array}{l}\text { Universidad de Granada } \\
\text { (Spain) }\end{array}$ & Article & 21 \\
\hline 12 & "Medios de comunicación en internet: algunas tendencias" (Díaz-Noci, 2010) & $\begin{array}{l}\text { Universitat Pompeu Fabra } \\
\text { (Spain) }\end{array}$ & Editorial & 21 \\
\hline 13 & $\begin{array}{l}\text { "Ciencia 2.0: catálogo de herramientas e implicaciones para la actividad investi- } \\
\text { gadora" (Cabezas-Clavijo; Torres-Salinas; Delgado-López-Cózar, 2009) }\end{array}$ & $\begin{array}{l}\text { Universidad de Granada } \\
\text { (Spain) }\end{array}$ & Article & 20 \\
\hline 14 & $\begin{array}{l}\text { "Excellence with leadership: The crown indicator of SCImago Institutions Rankings } \\
\text { Iber Report" (Jeremic; Jovanovic-Milenkovic; Radojicic; Martic, 2013) }\end{array}$ & University of Belgrade (Serbia) & Article & 19 \\
\hline 15 & $\begin{array}{l}\text { "World shares of publications of the USA, EU-27, and China compared and pre- } \\
\text { dicted using the new Web of Science interface versus Scopus" (Leydesdorff, 2012) }\end{array}$ & $\begin{array}{l}\text { University of Amsterdam (Ne- } \\
\text { therlands) }\end{array}$ & Article & 19 \\
\hline 16 & $\begin{array}{l}\text { "Uso de Twitter y Facebook por los medios iberoamericanos" (García-De-Torres; } \\
\text { Yezers'ka; Rost; Calderín; Edo; Rojano; Said-Hung; Jerónimo; Arcila; Serrano-Telle- } \\
\text { ría; Sánchez-Badillo; Corredoira, 2011) }\end{array}$ & $\begin{array}{l}\text { Universidad CEU Cardenal He- } \\
\text { rrera y Universidad Internacio- } \\
\text { nal Valenciana (Spain) }\end{array}$ & Editorial & 19 \\
\hline 17 & $\begin{array}{l}\text { "Multimedialidad en la prensa digital. Elementos multimedia y sistemas de recupe- } \\
\text { ración en los principales diarios digitales españoles" (Guallar; Rovira; Ruiz, 2010) }\end{array}$ & $\begin{array}{l}\text { Universitat de Barcelona } \\
\text { (Spain) }\end{array}$ & Article & 19 \\
\hline 18 & $\begin{array}{l}\text { "Google Scholar como herramienta para la evaluación científica" (Torres-Salinas; } \\
\text { Ruiz-Pérez; Delgado-López-Cózar, 2009) }\end{array}$ & $\begin{array}{l}\text { Universidad de Granada y Uni- } \\
\text { versidad de Navarra (Spain) }\end{array}$ & Article & 18 \\
\hline
\end{tabular}

Table 10. Authors with the highest number of most cited publications

\begin{tabular}{|c|c|c|}
\hline \multicolumn{2}{|c|}{ Publications ( $\mathrm{N}=18$ ) } & \multirow{2}{*}{ Authors } \\
\hline $\mathbf{n}$ & $\%$ & \\
\hline 4 & $4(22.22 \%)$ & Torres-Salinas \\
\hline 3 & $3(16.66 \%)$ & Delgado-López-Cózar \\
\hline 2 & $2(11.11 \%)$ & Díaz-Noci; Guallar; Kousha; Leydesdorff; Thelwall \\
\hline 1 & 1 (5.55\%) & $\begin{array}{l}\text { Abadal; Adams; Aleixandre-Benavent; Arcila; Bordons; Costas; Cabezas-Clavijo; Calderín; Casero-Ripollés; Co- } \\
\text { dina; Corredoira; Domingo; Edo; Ferrer-Sapena; García-De-Torres; Giménez-Toledo; González-Alcaide; Jeremic; } \\
\text { Jerónimo; Jiménez-Contreras; Jovanovic-Milenkovic; Martic; Masip; Micó-Sanz; Park; Pedraza-Jiménez; Peset; } \\
\text { Radojicic; Robinson-García; Rodríguez-Martínez; Rojano; Rost; Rovira; Ruiz; Ruiz-Pérez; Said-Hung; Salaverría; } \\
\text { Sánchez-Badillo; Sanz-Casado; Serrano-Tellería; Subirats-Coll; Valderrama-Zurián; Wagner; Yezers'ka; Zahedi }\end{array}$ \\
\hline
\end{tabular}

The findings described in the section 3.2 are related to the results identified in this section and EPI's performance too, but with some differential aspects of interest.

In terms of the publication language, $66.67 \%$ (12) of the most cited works published in the journal are in Spanish, while $33.33 \%(6)$ are in English. These percentages are favorable to the presence of English, but if we consider the total production of EPI (87.77\% in Spanish and $12.14 \%$ in English). There is a higher presence of English-language publications in the most cited publications. 
The organizations with the highest number of publications cited are Universidad de Granada, Universidad de Navarra and Universitat Pompeu Fabra with 4 publications and the Universitat de Barcelona and University of Wolverhampton with 2 publications each.
Table 11. Countries with the highest number of most cited publications

\begin{tabular}{|c|c|l|}
\hline \multicolumn{2}{|c|}{$\begin{array}{c}\text { Publications } \\
(\mathbf{N}=\mathbf{1 8})\end{array}$} & \multicolumn{2}{c}{ Countries } \\
\cline { 1 - 2 } $\mathbf{n}$ & $\%$ & \\
\hline 13 & 72.22 & Spain \\
\hline 3 & 16.66 & Netherlands \\
\hline 2 & 11.11 & United Kingdom \\
\hline 1 & 5.55 & Argentina; Italy; Peru; Portugal; Serbia; South Korea; United States; Venezuela \\
\hline
\end{tabular}

\section{Science mapping analysis of El profesional de la información}

EPI's evolution is presented below, identifying and visualizing the main thematic areas year by year from 2006 to 2017 using SCIMAT.

\subsection{Analysis of the content of the articles published from 2006 to 2017}

In order to visualize and analyze the evolution of the main themes within EPI, Figure 5 shows the strategic diagrams from 2006 to 2017, including the number of publications that each theme concentrates and the number of citations (in parentheses) achieved by each one according to the results obtained from the query applied in SSCI.

It is important to bear in mind that the one publication may be included in several themes, depending on their keywords used for its classification. In addition, the Motor themes and Basic and transversal themes are considered as the themes that contribute to develop and consolidate a knowledge field or a journal for their density and centrality.

Taking into account the strategic diagrams from figure 5, Table 12 shows the main research topics developed and their performance according to the number of publications from 2006 to 2017. On the other hand, Annex 1 details the evolution of each period and the research themes covered by each main research theme.

Table 12. Main research themes of EPI from 2006 to 2017

\begin{tabular}{|c|c|c|c|c|c|c|c|}
\hline \multirow{2}{*}{ Themes } & \multirow{2}{*}{ Publications } & \multirow{2}{*}{ Cites } & \multirow{2}{*}{$\begin{array}{c}\text { Cites/ } \\
\text { publication }\end{array}$} & \multicolumn{4}{|c|}{ Quadrants } \\
\hline & & & & Q1 & Q2 & Q3 & Q4 \\
\hline WEBSITES & 73 & 189 & 2,6 & 3 & 1 & - & 5 \\
\hline SOCIAL-NETWORKS & 67 & 310 & 4,6 & 2 & - & - & 5 \\
\hline INTERNET & 50 & 155 & 3,1 & 2 & - & - & 3 \\
\hline BOOKS & 50 & 183 & 3,7 & 4 & 1 & - & 2 \\
\hline ACADEMIC-LIBRARIES & 43 & 137 & 3,2 & - & 2 & 2 & 3 \\
\hline JOURNALISM & 42 & 107 & 2,5 & - & - & - & 3 \\
\hline TWITTER & 38 & 27 & 0,7 & - & - & - & 2 \\
\hline WEB-2.0 & 37 & 162 & 4,4 & 1 & - & 1 & 2 \\
\hline REPOSITORIES & 30 & 100 & 3,3 & - & 1 & - & 2 \\
\hline TELEVISION & 30 & 92 & 3,1 & - & - & - & 4 \\
\hline DATABASES & 27 & 76 & 2,8 & 4 & 3 & - & - \\
\hline ELECTORAL-CAMPAIGNS & 26 & 12 & 0,5 & - & - & - & 1 \\
\hline NEWSPAPERS & 23 & 24 & 1,0 & 1 & - & - & 2 \\
\hline INFORMATION-VISUALIZATION & 22 & 47 & 2,1 & - & 1 & 1 & 1 \\
\hline OPEN-ACCESS & 22 & 47 & 2,1 & 1 & 2 & 1 & - \\
\hline ONLINE-JOURNALISM & 21 & 97 & 4,6 & 1 & - & - & 1 \\
\hline COMMUNICATION-STRATEGIES & 19 & 13 & 0,7 & - & 1 & - & - \\
\hline DIGITAL-COMMUNICATION & 19 & 4 & 0,2 & - & - & - & 1 \\
\hline DIGITALIZATION & 19 & 61 & 3,2 & 3 & - & 1 & - \\
\hline EBOOKS & 19 & 23 & 1,2 & - & 1 & - & 1 \\
\hline INNOVATION & 19 & 27 & 1,4 & 1 & 2 & - & 1 \\
\hline BIBLIOMETRICS & 18 & 73 & 4,1 & - & 3 & 1 & - \\
\hline BIG-DATA & 18 & 51 & 2,8 & - & 1 & - & 2 \\
\hline MUSEUMS & 18 & 30 & 1,7 & - & - & 1 & 1 \\
\hline LIBRARY-SERVICES & 16 & 31 & 1,9 & - & - & - & 1 \\
\hline SOCIAL-MEDIA & 15 & 39 & 2,6 & 1 & - & - & 1 \\
\hline
\end{tabular}




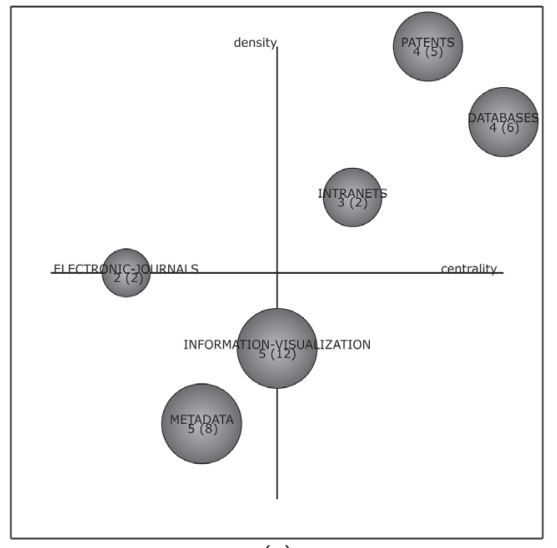

(a)
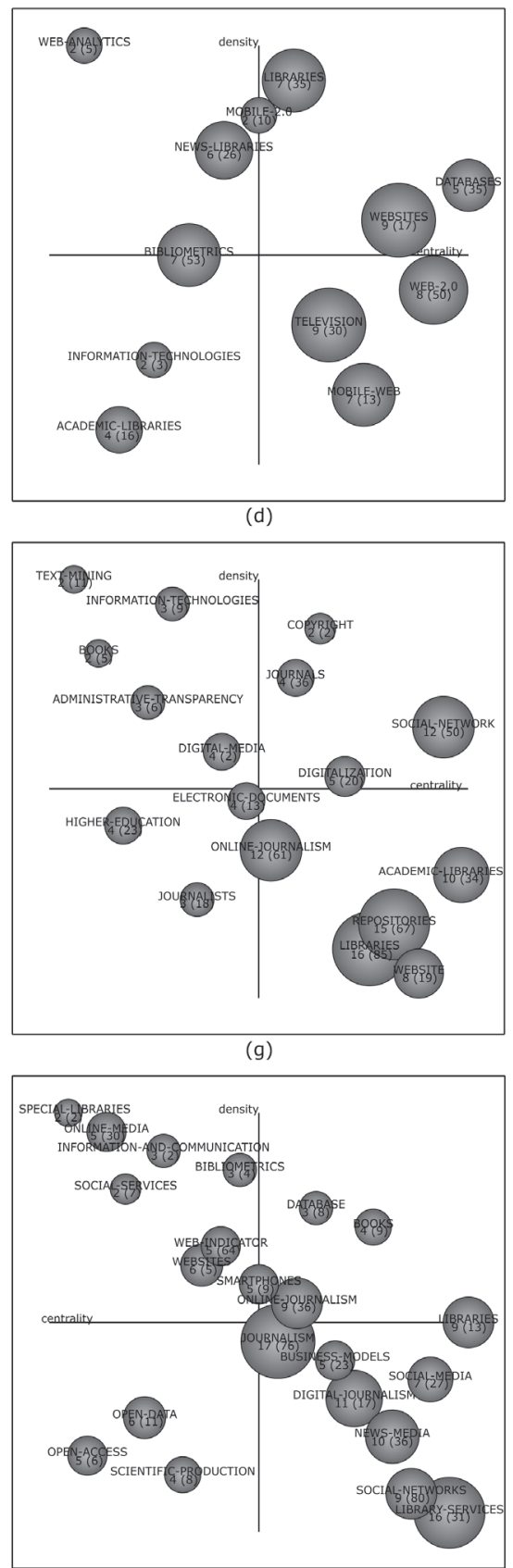

(j)

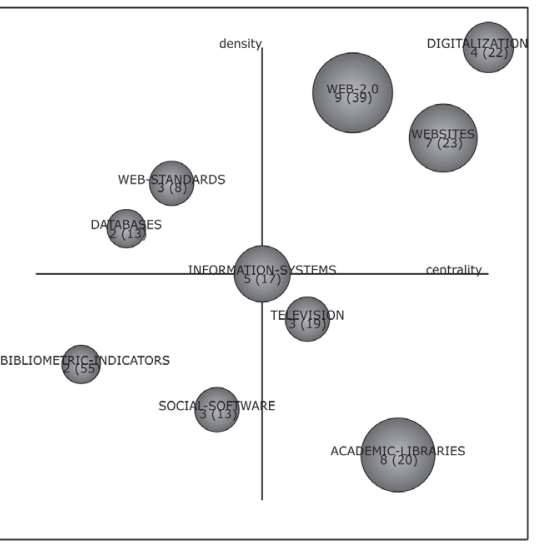

(b)

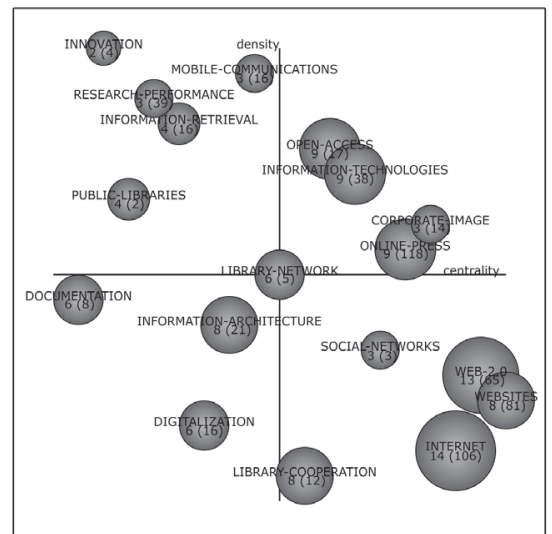

(e)
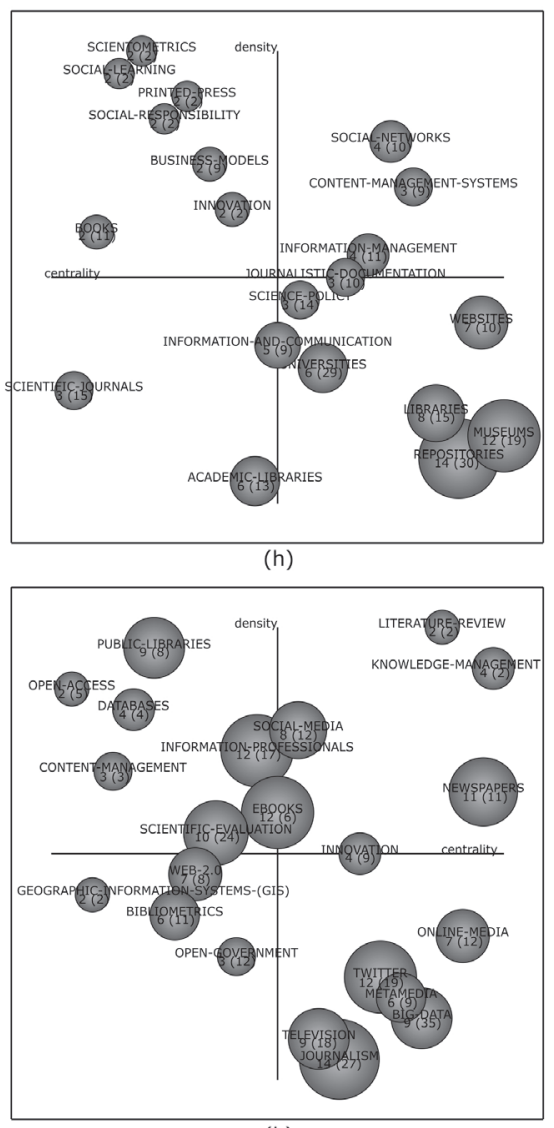

(k)
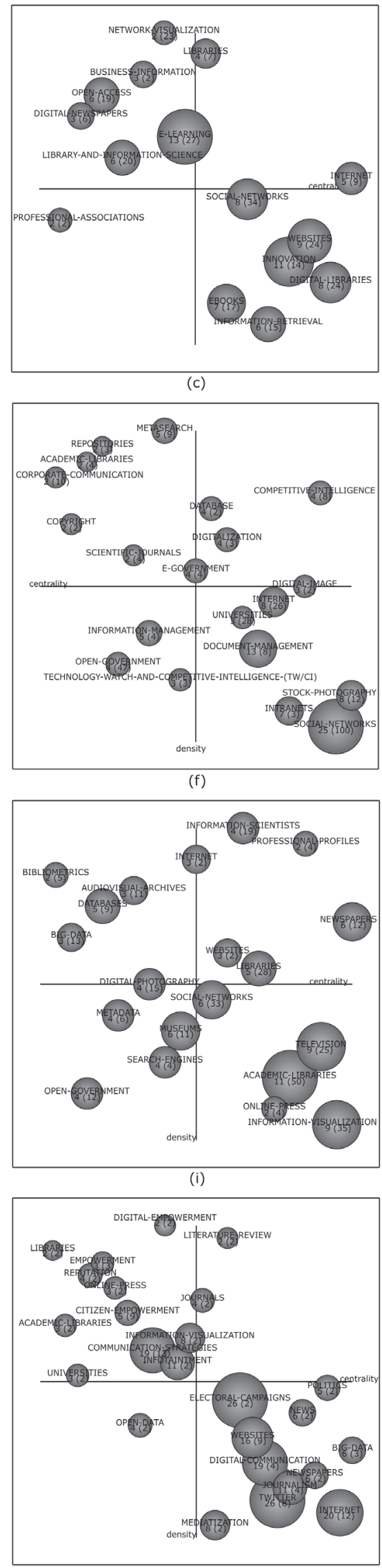

(I)

Figure 5. Strategic diagrams (a) 2006, (b) 2007, (c) 2008, (d) 2009, (e) 2010, (f) 2011, (g) 2012, (h) 2013, (i) 2014, (j) 2015, (k) 2016 and (l) 2017 
These results are aligned with the analyses carried out by Ferran-Ferrer et al. (2017) and Guallar et al. (2017), in which are identified as relevant themes within the journal:

- Communication

- Information technologies

- Metric studies of information

- Resources and sources of information

- Information and services units.

\subsection{Conceptual evolution map}

In accordance with the strategic diagrams, Figure 6 shows the evolution of the main thematic areas in EPI, the relationship between them during the period analyzed (2006-2017) and the main performance indicators for each one. In addition, the quality of the relationship between the different themes is represented by the characteristics of the line (Cobo et al., 2015; Sternitzke; Bergmann, 2009).

Considering the previous map and the thematic analyses carried out by Ferran-Ferrer et al. (2017) and Guallar et al. (2017) to the Spanish scientific journals of Library and Information Science as a starting point, the main themes and research lines related to the journal were identified and classified within six thematic areas:

- Resources and sources of information (green area)

- Auxiliary techniques and other disciplines (yellow area)

- Internet and web 2.0 (red area)

- Communication (purple area)

- Big and open data (gray area)

- Metric studies of information (blue area).
Resources and sources of information is the most representative thematic area of the conceptual evolution map

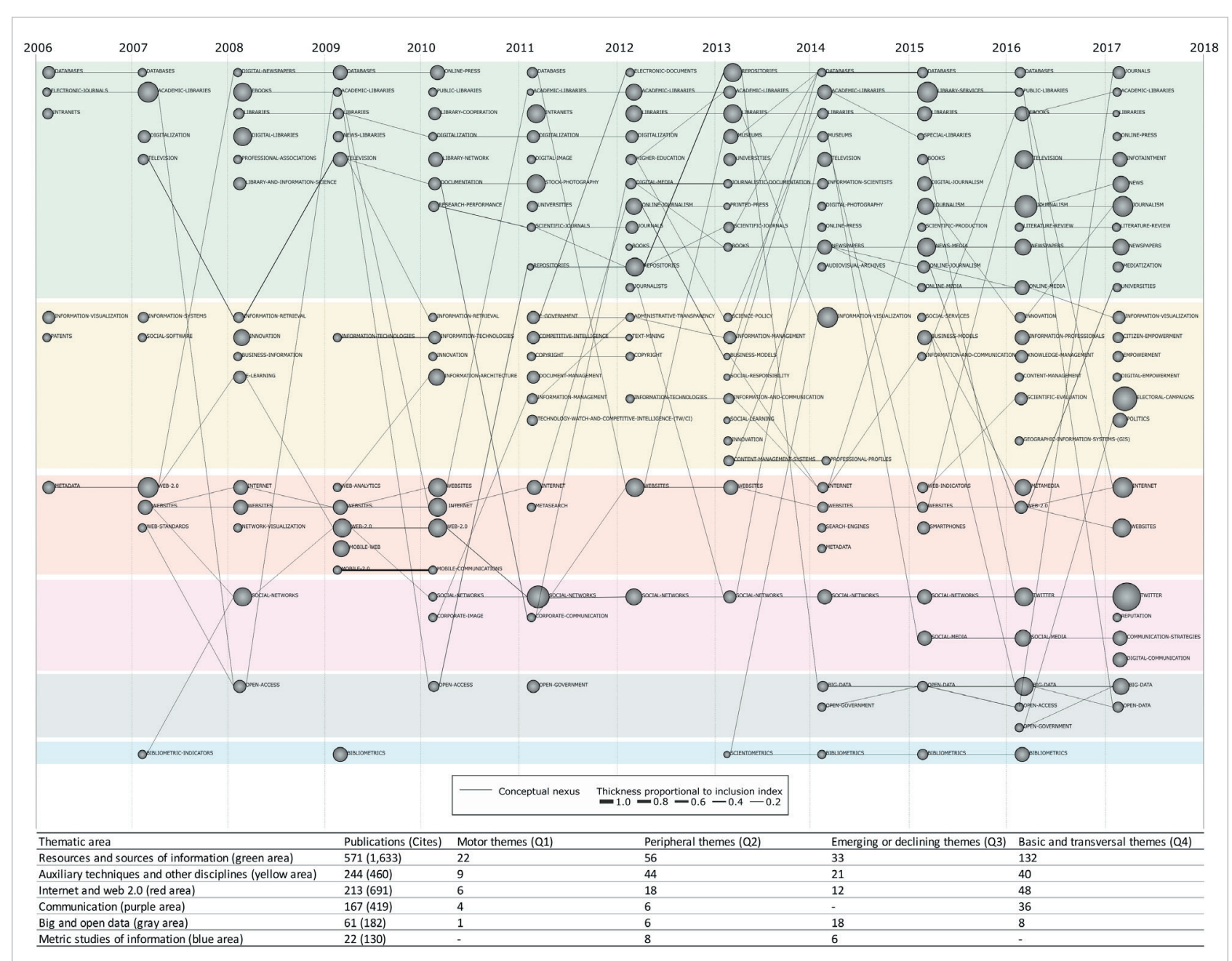

Figure 6. EPI conceptual evolution map (2006-2017) 


\section{Resources and sources of information (green area)}

This is the most representative thematic area within the conceptual evolution map (figure 9). It accounts for 571 publications and 1,633 citations with regard to the total number of publications and citations collected in the analyzed period. In terms of structure and thematic composition, it is distributed in all four quadrants during all the years analyzed, which reflects a balance and constancy in its development. This thematic area covers motor themes related to:

- BOOKS

- DATABASES

- DIGITALIZATION

- INFORMATION-SCIENTISTS

- INTRANETS

- JOURNALS

- BOOKS

- LITERATURE-REVIEW

- NEWSPAPERS

- ONLINE-JOURNALISM

In this thematic area, information products or primary sources (such as books, academic journals and digital press), secondary sources (databases), professionals, methods and processes (digitalization) are appreciated.

\section{Auxiliary techniques and other disciplines (yellow area)}

It is the second thematic area within the map in terms of the number of publications, including 244 publications and 460 citations. Its structure and thematic composition behave in a similar way to the previous thematic area, in a balanced and constant way. Its themes are principally:

- INFORMATION-VISUALIZATION

- INNOVATION

- ELECTORAL-CAMPAIGNS

- INFORMATION-TECHNOLOGIES

- INFORMATION-MANAGEMENT

- BUSINESS-MODELS

- INFORMATION-ARCHITECTURE

- INFORMATION-AND-COMMUNICATION

- INFORMATION-PROFESSIONALS

- INFORMATION-RETRIEVAL

This thematic area covers a variety of themes, most of which are unrelated.

\section{Internet and web $\mathbf{2 . 0}$ (orange area)}

It is the third thematic area within the map in terms of the number of publications with 213 publications and 691 citations. Its structure and thematic composition are distributed within all four quadrants, especially in the second one. Its specific themes are:

- INTERNET

- METADATA

- METAMEDIA

- METASEARCH

- MOBILE-2.0

- MOBILE-COMMUNICATIONS

- MOBILE-WEB

- NETWORK-VISUALIZATION

- SEARCH-ENGINES

- SMARTPHONES

- TEXT-MINING

- WEB-2.0

- WEB-ANALYTICS

- WEB-INDICATORS

- WEBSITES

- WEB-STANDARDS

Their main research line is the design, development and use of websites, also highlighting research lines related to mobile technologies and devices.

\section{Communication (pink area)}

It is the fourth thematic area with 167 publications and 419 citations. Its structure and thematic composition are distributed in the first, second and fourth quadrant in a balanced pattern. This thematic area is covered specifically: 
- COMMUNICATION-STRATEGIES

- CORPORATE-COMMUNICATION

- CORPORATE-IMAGE

- DIGITAL-COMMUNICATION

- REPUTATION

- SOCIAL-MEDIA

- SOCIAL-NETWORKS

- TWITTER

Social networks stand out as its main research line (including social media, reputation and Twitter) and communication and corporate communication appear as other guidelines.

Big and open data (grey area)

This thematic area covers 61 publications and 182 citations. Its structure and thematic composition are distributed in all four quadrants, particularly in the second and third during the last years of the evaluated period. This thematic area covers themes related to:

- BIG-DATA

- OPEN-ACCESS

- OPEN-DATA

- OPEN-GOVERNMENT.

This is a smaller thematic area with fewer themes than the previous ones.

Metric studies of information (blue area)

It ranks sixth with 22 publications and 130 citations. Its structure and thematic composition are concentrated in the second and third quadrants. This thematic area covers themes related to:

- SCIENTOMETRICS

- BIBLIOMETRICS

- BIBLIOMETRIC-INDICATORS.

Like in the previous one, it is a small thematic area quantitatively and it concentrates a few themes, but it highlights by its dynamism and significant citations.

It is important to point out that the first and fourth quadrants, relevant for the development of the journal, concentrate $52.17 \%$ of the research lines. This weight could be considered as a reflection of the interest of the academic, scientific and business communities in the thematic areas and research lines developed in the journal, which is also reflected in its growth and the continuity of the themes included in these quadrants.

\section{Conclusions}

The evolution of El profesional de la información is positive since its launch to date. In addition, given the large volume of publications and citations received, as well as the research themes identified and their evolution in the main databases, it is expected that the scientific community interest for the journal continues or even keeps growing over the coming years.

In the bibliometric performance analysis, EPI covers 1,448 researchers from 436 organizations and 32 different countries from 2006 to 2017. It has published 1,038 publications with 2,585 citations according to WoS, which the most productive authors are Codina, Torres-Salinas, Guallar, Peset, Delgado-López-Cózar, Ferrer-Sapena, Marcos, Pérez-Montoro, Rovira, Abadal, Baiget, Eíto-Brun, Jiménez-Contreras and Rodríguez-Gairín and the most cited are Torres-Salinas, Delgado-López-Cózar, Guallar, Codina, Leydesdorff, Peset, Ferrer-Sapena, Casero-Ripollés, Abadal, Thelwall, Kousha, Aleixandre-Benavent and Jiménez-Contreras. The correspondence between the most productive and most cited authors reflects the balance and quality of the publications included within the journal.

The most productive organizations in Spain have been:

- Universitat de Barcelona

- Universitat Pompeu Fabra

- Universidad de Granada

- Universidad Carlos III de Madrid

- Universidad Complutense de Madrid.
The correspondence between the most productive and most cited authors reflects the balance and quality of the publications included within the journal 
At the international level they highlight:

- University of Amsterdam (Netherlands)

- Universidad de Antioquia (Colombia)

- Universidad Nacional Autónoma de México (Mexico)

- University of Wolverhampton (United Kingdom)

- Max Planck Gesellschaft (Germany)

- Universidad Montpellier III (France)

- Universidad Nacional de Córdoba (Argentina)

- Loughborough University (United Kingdom)

- Université Catholique de Louvain (Belgium).

In line with the above, the journal presents an h-index of 18, an indicator that reflects the number of reference publications for their impact on its development. This group of publications concentrate 428 citations (including self-citations) and present an average of 23.78 citations each. The authors with more than one publication within the most cited are Torres-Salinas, Delgado-López-Cózar, Díaz-Noci, Guallar, Kousha, Leydesdorff and Thelwall.

With regard to the organizations with the highest number of most cited publications, the Universidad de Granada, Universidad de Navarra and Universidad Pompeu Fabra with 4 publications and the Universidad de Barcelona and University of Wolverhampton with 2 publications each. This coincides with the results obtained initially, which reflects a coherence between productivity and the impact of authors and organizations.

On the other hand, the journal's conceptual evolution map reveals its specialization in themes such as: communication, information, indicators, libraries and information technologies, with important considerations to the use and treatment of data, as well as its storage and dissemination. It is important to point out that the evolution of the journal clearly shows a current approach, attending to the general needs of the scientific and academic community at all

This article is one of the first to evaluate the evolution of a journal using SciMAT times. The main motor and cross-cutting themes are those related to internet, web 2.0, social networks, digitalization, libraries and databases, mainly. The most important peripheral and emerging themes include the use of information technologies, open access to data, visualization of information, open government and innovation.

It has also been appreciated that the evolution of the thematic areas and their role in the development of the journal have been different:

- Sources of information and resources: this is the thematic area with the greatest weight within the journal, and it is mainly constituted by transversal themes that have been added in a constant manner during the period analyzed.

- Auxiliary techniques and other disciplines: it is the second area with the greatest weight and it is mainly composed for peripheral themes. This thematic area, in contrast with the previous one, it has shown an upward evolution until 2013 where it reached a maximum of 8 topics, to go down to a single topic in 2014 and start an evolution again.

- Internet and web 2.0: a thematic area composed mainly for transversal themes, which registered its main evolution from 2006 to 2010, recording a decrease in the number of themes in the following years.

- Communication and big and open data: these are two thematic areas that focus their evolution in the most recent years, and are mainly composed of transversal themes and peripheral themes, respectively.

- Metric studies of information: It concentrates a single theme per year, from 2013 to 2016 being its period of greatest activity, with mainly peripheral themes.

It is important to note that this analysis allows the identification of common themes that can be used to achieve the research lines related to the purpose and objectives of El profesional de la información.

It can be pointed out that this article is one of the first in the literature to present the use of SciMAT to evaluate the evolution of a journal, highlighting that this bibliometric software, unlike others, allows analyzing the evolution of the main research themes included in a publication or in a group of publications by periods and based on their centrality and density. The latter aspect can be considered the most relevant, since the organization of the themes into four categories: Motor, Peripheral, Emerging or declining and Basic and transversal, supports the identification and analysis of the journal's corpus, enabling a journal's managers to evaluate its evolution and researchers to guide their research.

For future research, the analysis of the main research themes identified is proposed from a more complete approach, with the idea of analyzing how they interact with the development of a knowledge area and how they are approached by other journals within the same region or at a global level. In addition, it is recommended to deepen the relationship that exists between authors and organizations, in order to identify the groups that promote development in the themes, in order to identify new trends and opportunities in these research fields, as well as the patterns of collaboration that may exist between them.

The organization of themes in the four categories allows the journal's managers to evaluate its evolution and the researchers to guide their research 


\section{Annexes}

\section{A.1. Year to year analysis of the main research themes from 2006 to 2017}

In order to visualize and analyze the evolution of the main themes within EPI, the strategic diagrams are presented below. The strategic diagrams include further information about publications and citations, and these are arranged in four groups to facilitate the visualization.

Figure A1.1 shows the strategic diagrams for the period 2006, 2007 and 2008, in which 6, 10 and 15 themes were recorded respectively. In 2016, the themes were mainly Motor Themes and Emerging or Declining Themes. In 2007, the themes were divided into all four quadrants, in contrast with 2008, where the themes were mainly divided into the quadrants of Peripheral Themes and Basic and Transversal Themes.

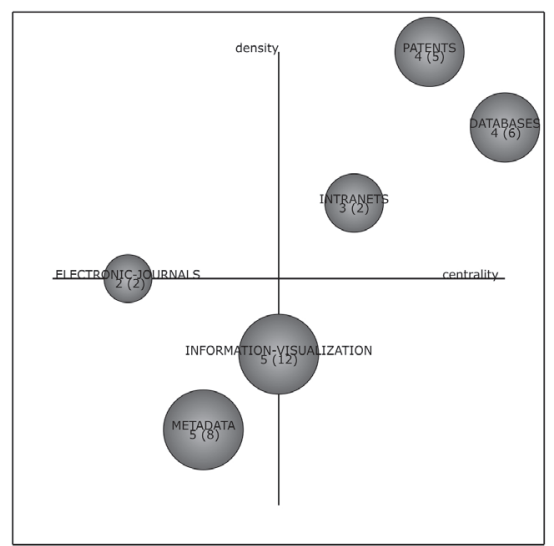

(a)

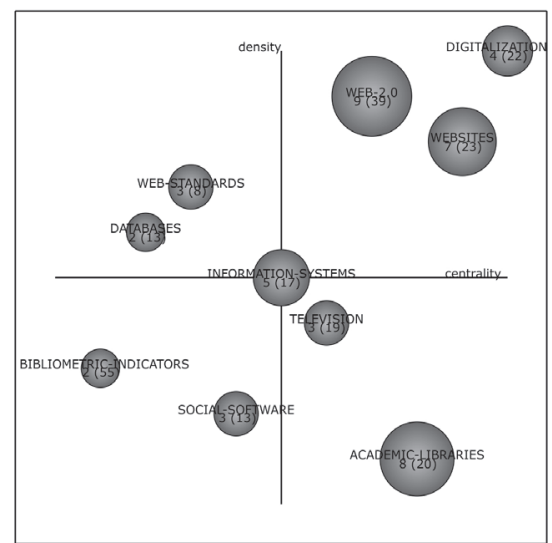

(b)

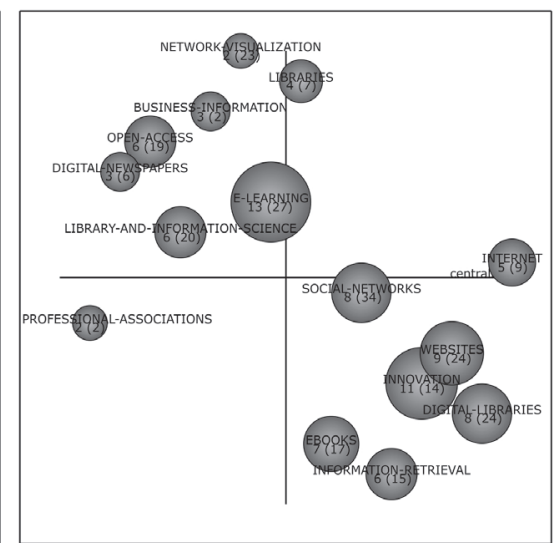

(c)

Figure A1.1. Strategic diagrams. (a) Period 2006 (b) Period 2007 and (c) Period 2008

In 2006, 6 themes are identified, but only DATABASES, INTRANETS and PATENTS can be considered relevant for the development and consolidation of the journal. The main components of these themes are presented below:

- DATABASES: Internet searching skills; Information retrieval; Information sources; Interfaces; Catalogues; Subject retrieval; Systematic reviews; Secondary literature; Public access catalogs; Optimal search strategies.

- INTRANETS: Content management; Information technologies; Management indicators; Knowledge management; Intranet management; Human resources; Document and records management.

- PATENTS: Information and communication; Bibliometrics; UNE 166006; Technology watch and competitive intelligence; Technological activity; Scientific production; Research and development e innovation.

In 2007, DIGITALIZATION, WEBSITES, WEB 2.0, ACADEMIC-LIBRARIES, INFORMATION-SYSTEMS and TELEVISION were identified as the key themes for the development and consolidation of the journal and its main components are listed below:

- DIGITALIZATION: Media asset management; Integrated systems; Professional profiles; Television archives; Radiophonic documentation; Public domain.

- WEBSITES: Internet; Information for companies; Information sharing; Information socialization; Information architecture; Social networks; Video on demand; Universal library; Television on internet; Social economy; Multimedia production; Mass media information management; Media libraries.

- WEB 2.0: Information managers; Information specialists; Digital newspapers; Information scientists; Librarians; Web browsers; Web embedded semantics; Usage analysis; User agents; RSS; Record managers; Professional directories; Metadata; Library 2.0.

- ACADEMIC-LIBRARIES: Library concept; Library resources; Hybrid library; Learning objects; Learning support; Repositories; Weblogs; University policy; User training; Strategic planning; Research support; Quality management; Pedagogical tools; Online public access catalog; Online help.

- INFORMATION-SYSTEMS: Enterprise content management; Content management systems; Web content management systems; Source description framework; Semantic web.

- TELEVISION: Documentation centers; Digitizing; Audiovisual documentation; Audiovisual information; Open archive; TV archive; Record selection; Multimedia content management; Document management.

In 2008, eight main themes were identified, and only WEBSITES repeats as the main research theme. Listed below are the most relevant themes of the period:

- LIBRARIES: Digital collections; Bibliographic heritage; Universities; Professional experience; Librarian and information professionals.

- INTERNET: Network society; Linguistic forms; Information technologies users; Financial information; Document type; Electronic newspaper; Library network; Union catalogue; Web services; User measurement; User perception.

- DIGITAL-LIBRARIES: Information visualization; Co-citation; Co-authorship; Electronic documents; Visual interfaces; Syndication; Selective dissemination of information; RSS; Recommender systems; Network effects.

- EBOOKS: Electronic ink; Collection development; Electronic content; Languages; Print on demand; Market strategies; International publishers; Information mobility.

- INFORMATION-RETRIEVAL: Audiovisual information; Scientific information; Co-terms analysis; Television; Online public access catalog. 
- INNOVATION: Information in companies; Information needs; Information uses; Public libraries; Visualization of patent data; Talent management; Science policy; Patent information; Management of innovation; Patent analysis software.

- SOCIAL-NETWORKS: Communication research; Creativity; Bibliometric indicators; Social organization; Social behavior; Professional networks; Information science; Information structures; Facebook.

- WEBSITES: Collaborative environments; Computer attitudes; Content management; Cultural diversity, Webometrics; Visibility; Social network analysis; Search engines; Online social networks; MES centers; Library portal.

Figure A1.2 shows the strategic diagrams for the period 2009, 2010 and 2011, in which 12, 18 and 20 themes were considered respectively.

Between 2008 to 2009, a slight decrease in the number of themes caused by reduction in the number of publications was recorded. However, between 2010 and 2011, the number of publications significantly increases with respect to previous years

During the period 2009 and 2010, the main themes were distributed in all four quadrants, while in 2011, these were concentrated in the quadrants corresponding to the Peripheral themes and Basic and transversal themes.

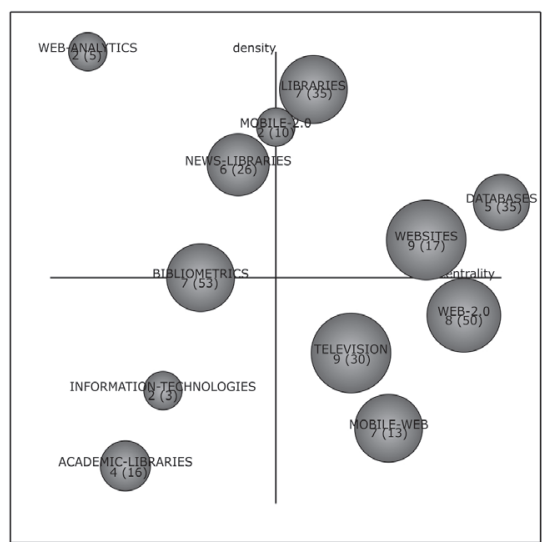

(d)

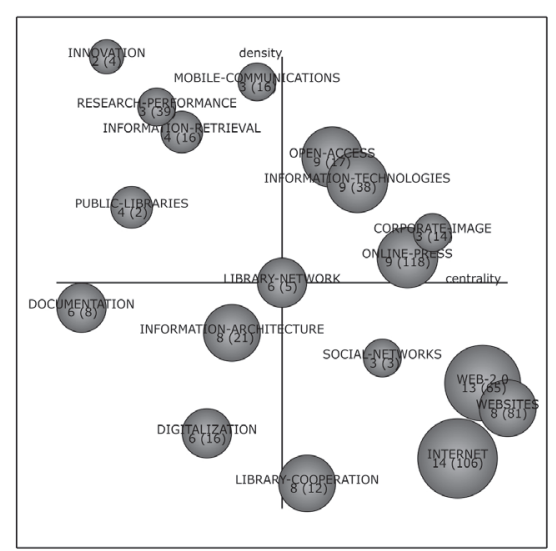

(e)

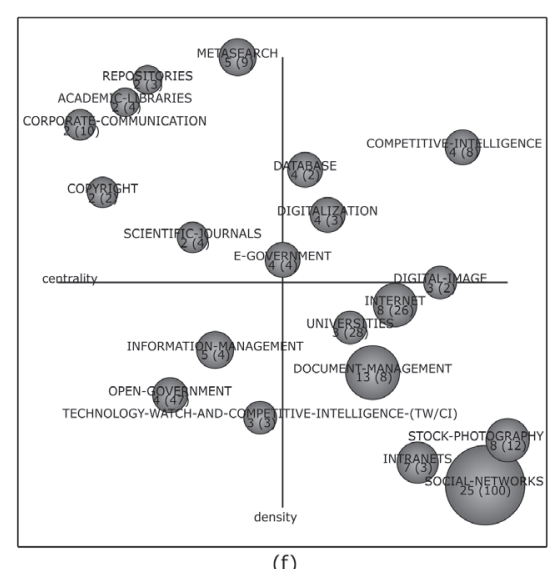

(f)

Figure A1.2. Strategic diagrams. (d) Period 2009, (e) Period 2010 and (f) Period 2011

In 2009, twelve research themes were identified, half of which may be considered relevant for the development and consolidation of the journal. The main components of these themes are presented below:

- DATABASES: Digital newspapers; Repositories; Web sources; Watch technology and competitive intelligence (TW/CI); Scientific production; Scientific and technical information; Search strategies; Search systems; Quality information; Patents; Online press; Online media.

- LIBRARIES: Distribution list; Digitalization; Content analysis; Information professionals; Librarians; Virtual communities; Technological changes; Scientific communication; Professional communication; Professional environment; Professional rethinking.

- WEBSITES: Internet; Google; Digital information sources; Information systems; Web analysis; Visibility; Social network services; Search engines; Sitemaps; Risk communication; Robots e International auctions.

- MOBILE-WEB: Mobile technologies; Local administration; Geolocation; Code transformation; Content adaptation; Mashup; Widgets; Ubiquitous connectivity; Use of mobile web; Browsers; Mobile devices.

- TELEVISION: Image description; Audiovisual documentation; Audiovisual information; Television archives; Press; Multimedia content management; Multimedia market; Media asset management; Journalism; Information retrieval; Information units.

- WEB-2.0: Logs; Datamining; Content syndication; Blogs; Social networks; Web mining; Social tagging; Social web; Science 2.0; Open data; Online reference management; News promotion.

In 2010, CORPORATE-IMAGE, INFORMATION-TECHNOLOGIES, ONLINE-PRESS, OPEN-ACCESS, INTERNET, LIBRARY-COOPERATION, SOCIAL-NETWORKS, WEBSITES and WEB-2.0 were identified as main research themes and its main components are listed below:

- CORPORATE-IMAGE: Customer relations; Business communication; Professional profiles; Information management; Image audit; Document processing; Corporate documentation.

- INFORMATION-TECHNOLOGIES: Domestic book market; Information professionals; Information seeking behavior; Social web; Publishing Industry; Picture archiving and communication systems; Knowledge management; Knowledge society; Health information; Foreign book market.

- ONLINE-PRESS: Digital media; Digital press archives; Cybermedia; Blogs; Web 2.0 adoption; Weblogs; Web newspaper; Online journalism; Mass communication; Credibility.

- OPEN-ACCESS: Library catalogues; Libraries; Repositories; Semantic web; Scholar communication; Professional future; Mobile devices; Conferences.

- INTERNET: Audiovisual management; Business models; Web visibility; Television; SEO; Place brands websites; Google; Email chain letters.

- LIBRARY-COOPERATION: E-learning; Education for knowledge society; Cooperation projects; Joint use libraries; Special libraries; Networking; Libraries networks; International cooperation.

- SOCIAL-NETWORKS: Creative commons; Audiovisual archives; Learning and informed environment; Content management; Cooperative network. 
- WEBSITES: Press offices; Newspapers; Network analysis; Mobile applications; Academic libraries; Content management systems; Social media marketing; Search engine marketing; Promotion strategies; Productive routines.

- WEB-2.0: Mass media; Journals; Intellectual property; Cyberjournalism; Community managers; Electronic newspaper; Information scientist; User generated content; Users relationship; Social media; Science 2.0; Personal data; Newsroom.

In 2011, ten key themes were identified as key factor to the development and consolidation of the journal. The main components of these themes are presented below:

- COMPETITIVE-INTELLIGENCE: Human information sources; Environmental scanning; Early warning; Decision making; Weak signals; Text mining; Strategic information management; Online research; Media mining; Information extraction.

- DATABASES: Computer science; Bibliographic references; Advanced management of personal information; Information processing; Information search; E-commerce.

- DIGITALIZATION: Cultural heritage; Channels of distribution; Business strategies; Audiovisual documentation; Audiovisual archives; Information access; Education programs.

- DIGITAL-IMAGE: Documentary photography; Digital collection management software; Content DM; User profiles; User restrictions; Image databases.

- DOCUMENT-MANAGEMENT: Digital documents; Digital records; Archival science; Record management; Qualitative research; Metadata; Knowledge management; Electronic records; Digital access.

- INTERNET: Networking; Information and communication; Theoretical analysis; Time estimates; Sociability; Social capital; Search task; Participatory culture.

- INTRANETS: Learning management systems; Internal communication; Intranet development; Information management in the cloud; Government 2.0; Web services; Virtualization; Technology in the cloud; Open source software; Open source.

- SOCIAL-NETWORKS: Real time web; Recommender systems; Microblogging; Multimedia information service; Information sources; Facebook; Web 2.0; User generated content; Social web; Social media; Semantic web; Twitter.

- STOCK-PHOTOGRAPHY: Photo libraries; Open repositories; Online information storage and retrieval; News libraries; Research needs; Photographic documentation; Photographic management.

- UNIVERSITIES: Citation analysis; Bibliometric indicators; Academic network; Mass media; Information research.

During the period 2012-2014, a decrease in the number of publications with respect to previous periods was recorded, but the number of research themes did not decrease. The research themes identified for this period were 17, 20 and 20 respectively, as can be seen in the Figure A1.3.

In the same period, the most relevant research themes were concentrated in the Basic and transversal themes quadrant, yet all period have research themes in the three remaining quadrants.

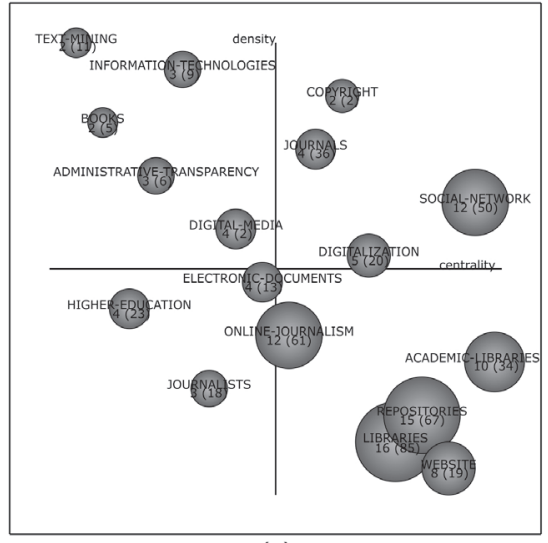

(g)

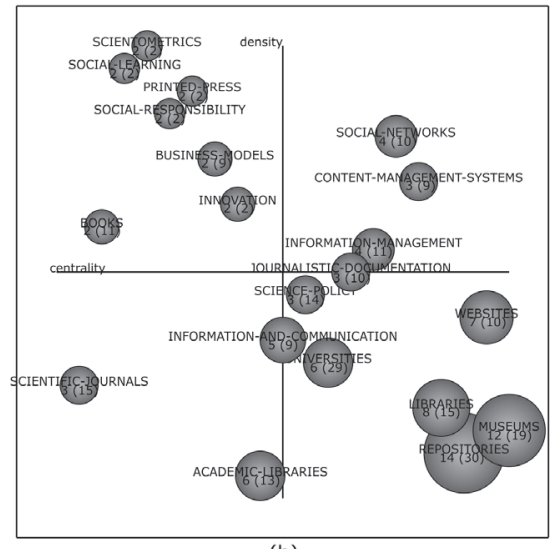

(h)

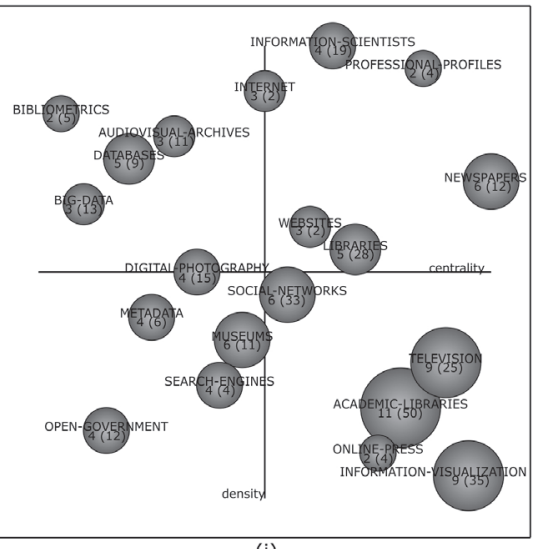

(i)

Figure A1.3. Strategic diagrams. (g) Period 2012, (h) Periods 2013 and (i) Periods 2014

In 2012, COPYRIGHT, DIGITALIZATION, JOURNALS, SOCIAL-NETWORKS, ACADEMIC-LIBRARIES, LIBRARIES, ONLINE-JOURNALISM, RESPOSITORIES and WEBSITES were identified as relevant themes for the development and consolidation of the journal. The main components of these themes are presented below:

- COPYRIGHT: Documentary heritage; Data protection; Digital GAP; Trade secrets; Regulation; Patents; Personal data protection; Outsourcing; Open data.

- DIGITALIZATION: E-Journals; Data compression; Digital archives; Digital collections; Web based services; Tagging; Podcasts; Library collections; Library management systems; Integrated library systems; Images managing.

- JOURNALS: Code of conduct; Scientific publication; Science citation index; Scientific information; Publication ethics; Publication patterns; Journal performance.

- SOCIAL-NETWORKS: Image processing; Geolocation; Facebook; Face recognition; Web 2.0; Web analytics; Twitter; Public opinion; Online reputation; Online participation; Legal advising.

- ACADEMIC-LIBRARIES: Document delivery; Electronic content; Virtual services; Virtual references; Reverence services; Reading patterns.

- LIBRARIES: Discovery software; Cloud computing; Ebooks; Semantic web; Metadata; Linked data; Knowledge organization systems.

- ONLINE-JOURNALISM: Digital journalism; Digital Press; Digital Press archives; Circulation media; Business models; Digital content; Digital newspapers; News libraries; Search systems; Printed press; Online press; Newspapers; Internet. 
- REPOSITORIES: Google Scholar Metrics; Data sharing; Democratic education; Discovery tools; Bibliometric indicators; Information seeking behavior; Scientific journals; Research data; Researchers profiles; Raw data; Open access; h-index; Google Scholar.

WEBSITES: Journalism; Corporate communication; Databases; Museums; Web page design; Process map; Online new consumers; News sources.

In 2013, eight main themes were identified, and where SOCIAL-NETWORKS, LIBRARIES, REPOSITORIES, WEBSITES repeat as the main research themes. Listed below are the most relevant themes of the period:

- CONTENT-MANAGEMENT-SYSTEMS: Broadcasting companies; Broadcasting documentation; Professional profiles; Webometrics; Semantic markup; Media documentation; Documentary archive.

- INFORMATION-MANAGEMENT: Financial system; Decisional information; Categorization; Administrative structures; Information professionals; Risk management; Library science; Information science; Information studies; Financial information.

- SOCIAL-NETWORKS: Information services; Cooperative learning; Television; Twitter; Social media policies; Open educational resources; Multicultural education; Mass media; Learning technologies; Journalism.

- INFORMATION-AND-COMMUNICATION: Information technologies; Information technology infrastructure library; ISO/IEC 20000; Information technology service management.

- JOURNALISTIC-DOCUMENTATION: Document analysis; Statement; Information retrieval.

- LIBRARIES: Information visualization; Documentation; Visibility; Social return on investment; Return on investment.

- MUSEUMS: Drupal; Bibliographic heritage; Databases; Social web; Semantic web; Open source; Heritage libraries.

- REPOSITORIES: Data sharing; Digital preservation; Content management; Big data; Open archive; Scientific data; Research data; Professional publications; Open data; Open access; Linked data; Knowledge management.

- SCIENCE-POLICY: Databank; Data curation; Information policy; Scientific publication; National policy; International visibility; E-Science.

- UNIVERSITIES: Dashboards; Information systems; Quality assurance; Library and information science.

- WEBSITES: Data analysis; Digital archives; Content quality; Digital libraries; User evaluation; Geographic information systems; Search engine optimization; Search services; Information units; Information architecture.

In 2014, eleven key themes were identified as key factors to the development and consolidation of the journal. The main components of these themes are presented below:

- INFORMATION-SCIENTISTS: Documentation products; Critical thinking education; Critical thinking skills; Critical thinking training; Documentalists; Press rooms; Organization systems; Knowledge representation; Journalistic documentation; Historical memory.

- INTERNET: Information and communication; Gamification; Evaluation of digital sources; Digital influence; Social museum; Online courses; Information sources.

- LIBRARIES: Public libraries; Universal access; Social transformation; Science policy; Library statistics.

- NEWSPAPERS: Mass media; Content management systems; User generated content; Online journalism; Online media; Online communities.

- PROFESSIONAL-PROFILES: Content manager; Archive manager; News agencies; Digital archives; Digital newsroom; Content Management.

- WEBSITES: Co-citation; Consumption of scientific literature; Content representation; Webometrics; Journalism; Journal usage; Indexing; Documentary organization.

- ACADEMIC-LIBRARIES: Cyberinfrastructure; Digital libraries; Librarians; Special libraries; Social responsibility; Public policy; National information policy; Documentation center.

- INFORMATION-VISUALIZATION: Search and records retrieval; User centered design; Visual analytics; Visualization types; Text analysis; Text visualization; Storytelling; Social network visualization; Social network analysis.

- ONLINE-PRESS: Information overload; News interest; News overload; Consumer paying behavior; Community management.

- SOCIAL-NETWORKS: Facebook; Web 2.0; Task performance; Twitter; Social web; Social internet; Knowledge workers.

- TELEVISION: Broadcast advertising; Audiovisual documentation; Object classification; Managed document services; Information managers; Electronic press kits; Digital information.

Finally, during the period 2015, 2016 and 2017, an increase in the number of publications and research themes with respect to previous periods was recorded. The research themes identified for these periods were 22, 22 and 25 respectively, as shown in figure A1.4.

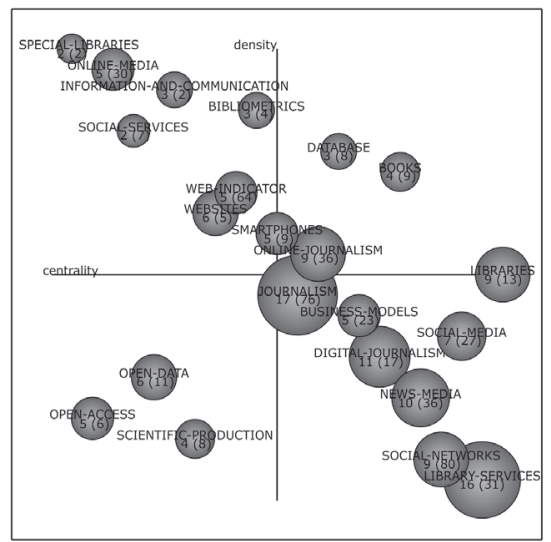

(j)

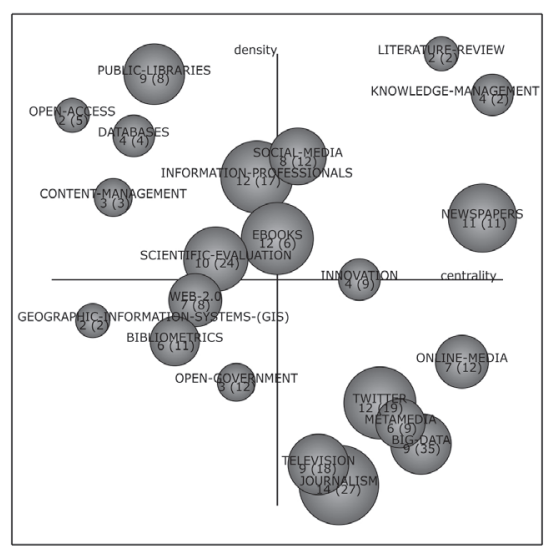

(k)

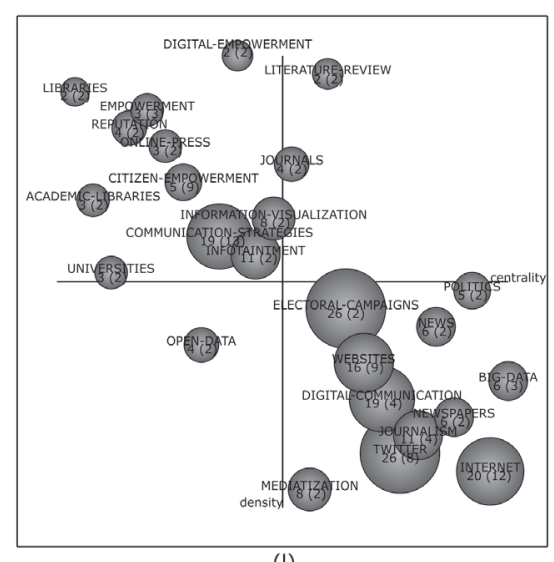

(1)

Figure A1.4. Strategic diagrams. (j) Period 2015, (k) Period 2016 and (I) Period 2017 
In 2015, the main research themes were identified in the Basic and transversal quadrant, although it presents themes in all quadrants, which reflects a homogeneous development of the themes. In this context, during 2016 and 2017 the most relevant themes were peripheral themes and basic and transversal themes.

In 2007, eleven research themes were considered as key factor to the development and consolidation of the journal and its main components are listed below:

- BOOKS: Bookstores; Virtual reading; Social web; Interactive communication.

- DATABASES: Information policy; Scientific journals; International collaboration e International visibility.

- LIBRARIES: Personal archives; Universities; Marketing strategies; Learning resources.

- ONLINE-JOURNALISM: Cyberjournalism; Blogs; Web 2.0 Visual an interactive features; multimedia stories.

- BUSINESS-MODELS: Digital consumers; Digital newspapers; Audiovisual content; Streaming; Mobile devises; Entertainment industry.

- DIGITAL-JOURNALISM: Digital storytelling; Science journalism; Journal articles; Impact journal; Information sources.

- JOURNALISM: Internet; Innovation; Digital media; Audiovisual communication; News organizations; Entrepreneurship.

- LIBRARY-SERVICES: Social integration; Academic libraries; Librarians; Public libraries; Scientific publication; Virtual services; Teaching and learning services.

- NEWS-MEDIA: Informational empowerment; Entrepreneurial journalism; Digital narrative; Press; Media organizations; Media studies; Independent press.

- SOCIAL-MEDIA: Online communities; Digital marketing; Transmedia and storytelling; Social marketing; Social media marketing; Social media strategies; Relationship marketing.

- SOCIAL-NETWORKS: Facebook; Communication studies; User generated content; Twitter; Scientific social networks, Participatory journalism; Online measuring tools.

In 2016, INNOVATION, KNOWLEDGE-MANAGEMENT, LITERATURE-REVIEW, NEWSPAPERS, SOCIAL-MEDIA, BIG-DATA, JOURNALISM, METAMEDIA, ONLINE-MEDIA, TELEVISION and TWITTER were identified as relevant themes for the development and consolidation of the journal. The main components of these themes are presented below:

- INNOVATION: Digital transformation; Artificial intelligence; Information technologies; Interactive communication; Digital creativity.

- KNOWLEDGE-MANAGEMENT: Knowledge management maturity; Innovation management; Online reviews; Maturity models; Management and planning.

- LITERATURE-REVIEW: Comprehensive analysis; Concept maps; Semantic maps; Risk management; Learning strategy; Knowledge maps; Information security culture; Information security management.

- NEWSPAPERS: Digital media; Journalism online; News libraries; Search engine optimization; News media; Media business models.

- SOCIAL-MEDIA: Communication competition; Consumer behavior; Brand building; Marketing campaigns; Media innovation; Libraries management; Information society; Information strategies.

- BIG-DATA: Information production; Information retrieval; Human computer interaction; Google; Datamining; Business model; RSS; Public information; Personalized advertising; Open data; Machine learning.

- JOURNALISM: Document management; Communicators; Active audiences; Community managers; Web analytics; Public interest; News; News dissemination; Journalists; Entrepreneurship.

- METAMEDIA: Digital reputation; Digital social networks; Value networks; Scientific social networks; Scientific metamedia; Professional networks; Media management barometer; Journalistic curation.

- ONLINE-MEDIA: Data journalism; Data journalists; Cybermedia; Online journalism; Geolocation and Data geolocation.

- TELEVISION: Audiovisual documentation; Audience measurement; Audiovisual language; Social audience; Focus groups.

- TWITTER: Facebook; Digital convergence; Digital language; Social networks; Smart cities; Public opinion; Participation mechanisms; Mobile devices.

Finally, in 2017, thirteen key themes were identified as key factor to the development and consolidation of the journal. The main components of these themes are presented below:

- JOURNALS: Reference management software; Publishing practices; Open sources; Open access; Library and information science.

- LITERATURE-REVIEW: Content design; Web design; User centered design; Taxonomies; Neuromarketing; Interaction designs.

- BIG-DATA: Personal data protection; Personal information; Organization of information; Open government; Machine learning; Supervised sentiment analysis; Privacy self-management; Political opinion.

- DIGITAL-COMMUNICATION: Political parties; Humanization of politics; Digital narrative; Transmedia; Strategic impression management; Public opinion; Political marketing.

- ElECTORAL-CAMPAIGNS: Facebook; Political communication; Customization; National Election; Persuasion.

- INTERNET: Digital journalism; Digital services; Web 2.0; YouTube; Mobile devices; Media education; Journalists; Digital inclusion.

- JOURNALISM: Mass media ethics; Journalism deontology; Innovation; Social journalism; Search engines; Situated learning; Reference communities; Public management; Online Journalism.

- MEDIATIZATION: Digital media; Social mobilization; Populism; News media; Media coverage.

- NEWS: Consumption of information; Sensationalism; Public services; Push notification; Mobile apps; Journalistic genres; Human interest.

- NEWSPAPERS: News consumption; Millennial audience; Multiculturalism; Journalistic design; Digital press; Strategic communication; Printed press; Political journalism.

- POLITICS: Digital activism; Sub-activism; Political information; Memes.

- TWITTER: Electoral communication; Digital methods; Social networks; Social platforms; Social network analysis; Political campaigns; Fandom studies.

- WEBSITES: E-Government; Digital storytelling; Corporate brand; Public information; Local information; Management of local governments. 


\section{References}

Abadal, Ernest (ed.) (2017). Revistas científicas. Situación actual y retos de futuro. Edicions Universitat Barcelona. ISBN: 9788491680383

http://diposit.ub.edu/dspace/bitstream/2445/117374/1/08744_887954_5145_.pdf

Abadal, Ernest (2018). “¿Cómo han cambiado BiD y las revistas españolas de documentación en los últimos veinte años?". BiD: Textos universitaris de biblioteconomia i documentació, n. 40, pp. 1-10.

https://doi.org/10.1344/BiD2018.40.11

Alcaide-Muñoz, Laura; Rodríguez-Bolívar, Manuel-Pedro; Cobo, Manuel-Jesús; Herrera-Viedma, Enrique (2017). "Analysing the scientific evolution of e-government using a science mapping approach". Government information quarterly, v. 34, n. 3, pp. 545-555.

https://doi.org/10.1016/j.giq.2017.05.002

Alonso, Sergio; Cabrerizo, Francisco-Javier; Herrera-Viedma, Enrique; Herrera, Francisco (2009). "h-Index: A review focused in its variants, computation and standardization for different scientific fields". Journal of informetrics, v. 3, n. 4, pp. 273-289.

https://doi.org/10.1016/j.joi.2009.04.001

Ardanuy, Jordi; Urbano, Cristóbal (2017). “The academic-practitioner gap in Spanish library and information science: An analysis of authorship and collaboration in two leading national publications". Journal of librarianship and information science, v. 51, n. 2, pp. 317-330.

https://doi.org/10.1177/0961000617726125

Arquero-Avilés, Rosario; Del-Río-Sadornil, José-Luis (2002). “Trayectoria y estudio de producción de la revista 'Documentación de las ciencias de la información' en su XXV aniversario (1976-2001)". Documentación de las ciencias de la información, v. 25, pp. 95-114.

https://core.ac.uk/download/pdf/38813645.pdf

Calderón-Garrido, Diego; Gustems-Carnicer, Josep (2018). “Análisis bibliométrico de la producción científica sobre educación musical en el período 2007-2016 en revistas incluidas en JCR". BiD: Textos universitaris de biblioteconomia i documentació, n. 41.

https://doi.org/10.1344/BiD2018.41.9

Callon, Michael; Courtial, Jean-Pierre; Laville, Francoise (1991). "Co-word analysis as a tool for describing the network of interactions between basic and technological research: The case of polymer chemistry". Scientometrics, v. 22, n. 1, pp. 155-205.

https://doi.org/10.1007/BF02019280

Callon, Michael; Courtial, Jean-Pierre; Penan, Hervé (1995). Cienciometría: la medición de la actividad científica: de la bibliometría a la vigilancia tecnológica. Gijón: Trea. ISBN: 8487733948

Castillo-Esparcia, Antonio; Rubio-Moraga, Ángel; Almansa-Martínez, Ana (2012). “La investigación en comunicación. Análisis bibliométrico de las revistas de mayor impacto del ISI". Revista latina de comunicación social, v. 11. https://doi.org/10.4185/RLCS-067-955-248-270

Cobo, Manuel-Jesús (2012). SciMAT: herramienta software para el análisis de la evolución del conocimiento científico. Propuesta de una metodología de evaluación. Tesis doctoral. Granada: Universidad de Granada. http://hdl.handle.net/10481/20201

Cobo, Manuel-Jesús; Chiclana, Francisco; Collop, Andrew; De-Ona, Juan; Herrera-Viedma, Enrique (2014). “A bibliometric analysis of the intelligent transportation systems research based on science mapping". IEEE transactions on inteIligent transportation systems, v. 15, n. 2, pp. 901-908.

https://doi.org/10.1109/TITS.2013.2284756

Cobo, Manuel-Jesús; López-Herrera, Antonio-Gabriel; Herrera-Viedma, Enrique; Herrera, Francisco (2011a). "An approach for detecting, quantifying, and visualizing the evolution of a research field: A practical application to the fuzzy sets theory field". Journal of informetrics, v. 5, n. 1, pp. 146-166.

https://doi.org/10.1016/j.joi.2010.10.002

Cobo, Manuel-Jesús; López-Herrera, Antonio-Gabriel; Herrera-Viedma, Enrique; Herrera, Francisco (2011b). "Science mapping software tools: Review, analysis, and cooperative study among tools". Journal of the American Society for Information Science and Technology, v. 62, n. 7, pp. 1382-1402.

https://doi.org/10.1002/asi.21525 
Cobo, Manuel-Jesús; López-Herrera, Antonio-Gabriel; Herrera-Viedma, Enrique; Herrera, Francisco (2012). "SciMAT: A new science mapping analysis software tool". Journal of the American Society for Information Science and Technology, v. 63, n. 8 , pp. $1609-1630$.

https://doi.org/10.1002/asi.22688

Cobo, Manuel-Jesús; Martínez, Miguel-Ángel; Gutiérrez-Salcedo, María; Fujita, Hamido; Herrera-Viedma, Enrique (2015). "25 years at Knowledge-based systems: A bibliometric analysis". Knowledge-based systems, v. 80, pp. 3-13. https://doi.org/10.1016/j.knosys.2014.12.035

Cobo, Manuel-Jesús; Wang, Wanru; Laengle, Sigifredo; Merigó, José M.; Yu, Dejian; Herrera-Viedma, Enrique (2018). "Co-words analysis of the last ten years of the International journal of uncertainty, fuzziness and knowledge-based systems". In: Int conf on information processing and management of uncertainty in knowledge-based systems. Springer. https://doi.org/10.1007/978-3-319-91479-4_55

Delgado-López-Cózar, Emilio (2001). “Las revistas españolas de ciencias de la documentación: productos manifiestamente mejorables". El profesional de la información, v. 10, n. 12, pp. 46-56.

http://www.elprofesionaldelainformacion.com/contenidos/2001/diciembre/10.pdf

El profesional de la información (n.d.). "Sobre EPI". El profesional de la información. http://www.elprofesionaldelainformacion.com/presentacion.html

Ferran-Ferrer, Núria; Guallar, Javier; Abadal, Ernest; Server, Adan (2017). "Research methods and techniques in Spanish library and information science journals (2012-2014)". Information research, v. 22, n. 1.

http://www.informationr.net/ir/22-1/paper741.html

Glenisson, Patrick; Glänzel, Wolfgang; Janssens, Frizo; De-Moor, Bart (2005). "Combining full text and bibliometric information in mapping scientific disciplines". Information processing \& management, v. 41, n. 6, pp. 1548-1572.

https://doi.org/10.1016/j.ipm.2005.03.021

González-Alcaide, Gregorio; Gorraiz, Juan; Hervás-Oliver, José-Luis (2018). "On the use of bibliometric indicators for the analysis of emerging topics and their evolution: Spin-offs as a case study". El profesional de la información, v. 27, n. 3, pp. 493-510.

https://doi.org/10.3145/epi.2018.may.04

Goyanes, Manuel; Rodríguez-Gómez, Eduardo-Francisco; Rosique-Cedillo, Gloria (2018). “Investigación en comunicación en revistas científicas en España (2005-2015): de disquisiciones teóricas a investigación basada en evidencias". EI profesional de la información, v. 27, n. 5, pp. 1281-1291.

https://doi.org/10.3145/epi.2018.nov.11

Guallar, Javier; Ferran-Ferrer, Núria; Abadal, Ernest; Server, Adán (2017). "Revistas científicas españolas de información y documentación: análisis temático y metodológico”. El profesional de la información, v. 26, n. 5, pp. $947-960$.

https://doi.org/10.3145/epi.2017.sep.16

He, Qin (1999). “Knowledge discovery through co-word analysis”. Library trends, v. 48, n. 1, pp. 26.

http://hdl.handle.net/2142/8267

Hirsch, Jorge E. (2005). "An index to quantify an individual's scientific research output". Proceedings of the National Academy of Sciences, v. 102, n. 46, pp. 16569-16572.

https://doi.org/10.1073/pnas.0507655102

López-Herrera, Antonio-Gabriel; Herrera-Viedma, Enrique; Cobo, Manuel-Jesús; Martínez, María-Ángeles; Kou, Gang; Shi, Yong (2012). "A conceptual snapshot of the first decade (2002-2011) of the International journal of information technology \& decision making". International journal of information technology \& decision making, v. 11, n. 2, pp. 247-270. https://doi.org/10.1142/S0219622012400020

López-López, Pedro; Díaz-Hernández, Rosa-Ana; Angulo-Benítez, Sara; Giménez-Toledo, Elea (2001). “Estudio bibliométrico y de calidad de la Revista general de información y documentación (1991-2000)". Revista general de información y documentación, v. 11, n. 1, pp. 11-32.

http://hdl.handle.net/10261/11582

López-Ornelas, Maricela; Cordero-Arroyo, Graciela (2005). “Un intento por definir las características generales de las revistas académicas electrónicas". Revista razón y palabra, v. 10, n. 43, pp. 1-33.

http://hdl.handle.net/10760/15700

López-Robles, José-Ricardo; Otegi-Olaso, Jose-Ramón; Arcos, Rubén; Gamboa-Rosales, Nadia-Karina; Gamboa-Rosales, Hamurabi (2018a). "Mapping the structure and evolution of JISIB: A bibliometric analysis of articles published in the Journal of intelligence studies in business between 2011 and 2017". Journal of intelligence studies in business, v. 8, n. 3, pp. 9-21.

https://ojs.hh.se/index.php/JISIB/article/view/362 
López-Robles, José-Ricardo; Otegi-Olaso, Jose-Ramón; Gamboa-Rosales, Nadia-Karina; Gamboa-Rosales, Hamurabi; Cobo, Manuel-Jesús (2018b). "60 years of business intelligence: A bibliometric review from 1958 to 2017". In: New trends in intelligent software methodologies, tools and techniques: Proceedings of the $17^{\text {th }}$ intl conf SoMeT_18. IOS Press. http://doi.org/10.3233/978-1-61499-900-3-395

López-Robles, José-Ricardo; Otegi-Olaso, José-Ramón; Porto-Gómez, Igone; Gamboa-Rosales, Nadia-Karina; Gamboa-Rosales, Hamurabi; Robles-Berumen, Hermes (2018c). "Bibliometric network analysis to identify the intellectual structure and evolution of the big data research field". In: Int/ conf on intelligent data engineering and automated learning. Springer.

https://doi.org/10.1007/978-3-030-03496-2_13

López-Robles, José-Ricardo; Otegi-Olaso, José-Ramón; Porto-Gómez, Igone; Cobo, Manuel-Jesús (2019). “30 years of intelligence models in management and business: A bibliometric review". International journal of information management, v. 48, pp. 22-38.

https://doi.org/10.1016/j.ijinfomgt.2019.01.013

Martínez, María-Ángeles; Herrera, Manuel; López-Gijón, Javier; Herrera-Viedma, Enrique (2014). “H-classics: Characterizing the concept of citation classics through H-index". Scientometrics, v. 98, n. 3, pp. 1971-1983.

https://doi.org/10.1007/s11192-013-1155-9

Moed, Henk F. (2009). "New developments in the use of citation analysis in research evaluation". Archivum immunologiae et therapiae experimentalis, v. 57, n. 1, pp. 13.

https://doi.org/10.1007/s00005-009-0001-5

Moral-Muñoz, José-Antonio; Cobo, Manuel-Jesús; Chiclana, Francisco; Collop, Andrew; Herrera-Viedma, Enrique (2016). "Analyzing highly cited papers in intelligent transportation systems". IEEE transactions on intelligent transportation systems, v. 17, n. 4, pp. 993-1001.

http://doi.org/10.1109/TITS.2015.2494533

Pérez-Álvarez-Ossorio, José-Ramón (1997). “Cobertura temática y procedencia institucional de los artículos publicados en la Revista española de documentación científica en sus veinte años de existencia”. Revista española de documentación científica, v. 20, n. 3, pp. 290-298.

https://doi.org/10.3989/redc.1997.v20.i3.584

Pérez-Cabezas, Verónica; Ruiz-Molinero, Carmen; Carmona-Barrientos, Inés; Herrera-Viedma, Enrique; Cobo, Manuel-Jesús; Moral-Muñoz, José-Antonio (2018). "Highly cited papers in Rheumatology: Identification and conceptual analysis". Scientometrics, v. 116, n. 1, pp. 555-568.

https://doi.org/10.1007/s11192-018-2712-z

Powell, Taman H.; Kouropalatis, Yiannis; Morgan, Robert E.; Karhu, Päivi (2016). “Mapping knowledge and innovation research themes: Using bibliometrics for classification, evolution, proliferation and determinism". International journal of entrepreneurship and innovation management, v. 20, n. 3-4, pp. 174-199.

http://doi.org/10.1504/IJEIM.2016.077960

Schreiber, Michael (2007). "Self-citation corrections for the Hirsch index". Europhysics letters (EPL), v. 78, n. 3, pp. 30002. http://ddoi.org/10.1209/0295-5075/78/30002

Schubert, András (2007). "Successive h-indices". Scientometrics, v. 70, n. 1, pp. 201-205.

https://doi.org/10.1007/s11192-007-0112-x

Somoza, Marta; Guallar, Javier; Rodríguez-Gairín, Josep-Manuel; Abadal, Ernest (2017) “Presencia de revistas españolas en bases de datos internacionales". En: Abadal, Ernest (ed.). Revistas científicas. Situación actual y retos de futuro. Edicions Universitat de Barcelona, pp. 161-178. ISBN: 9788491680383

http://hdl.handle.net/10760/32136

Sternitzke, Christian; Bergmann, Isumo (2009). "Similarity measures for document mapping: A comparative study on the level of an individual scientist". Scientometrics, v. 78, n. 1, pp. 113-130.

https://doi.org/10.1007/s11192-007-1961-z

Wang, Jian (2013). "Citation time window choice for research impact evaluation”. Scientometrics, v. 94, n. 3, pp. $851-872$. https://doi.org/10.1007/s11192-012-0775-9 